NBER WORKING PAPER SERIES

THE ACCUMULATION OF HUMAN AND NONHUMAN CAPITAL, REVISITED

Barbara M. Fraumeni

Michael S. Christian

Jon D. Samuels

Working Paper 21284

http://www.nber.org/papers/w21284

\author{
NATIONAL BUREAU OF ECONOMIC RESEARCH \\ 1050 Massachusetts Avenue \\ Cambridge, MA 02138 \\ June 2015
}

We thank Carol Moylan of the Bureau of Economic Analysis for her comments on this paper. The views expressed herein are those of the authors and do not necessarily reflect the views of the National Bureau of Economic Research, the Bureau of Economic Analysis, or the U.S. Department of Commerce.

At least one co-author has disclosed a financial relationship of potential relevance for this research. Further information is available online at http://www.nber.org/papers/w21284.ack

NBER working papers are circulated for discussion and comment purposes. They have not been peerreviewed or been subject to the review by the NBER Board of Directors that accompanies official NBER publications.

(C) 2015 by Barbara M. Fraumeni, Michael S. Christian, and Jon D. Samuels. All rights reserved. Short sections of text, not to exceed two paragraphs, may be quoted without explicit permission provided that full credit, including $\odot$ notice, is given to the source. 
The Accumulation of Human and Nonhuman Capital, Revisited

Barbara M. Fraumeni, Michael S. Christian, and Jon D. Samuels

NBER Working Paper No. 21284

June 2015

JEL No. D24,E01,E24

\begin{abstract}
In the 25 years since Jorgenson and Fraumeni (1989) published their first article on human capital, the U.S. National Income and Product Accounts (NIPA) and the SNA have changed significantly. The contribution of this paper is two-fold: Creation of a contemporary set of accounts which integrate human capital measures into the latest comprehensive revision of the U.S. national income accounts and an analysis of trends in human capital and national income account aggregates over the post-war period.

The paper is a national income accounting paper with production and factor outlay, income, receipt and expenditure, capital accumulation, and wealth accounts. All of these accounts are tied to the NIPAlaccounts, and supplemented with human capital estimates. A key feature of the human capital accounts lis presentation of human capital estimates in current and constant prices. The time period covered[is 1949-84 and 1998-2009.

We update the human capital national income accounts and examine trends in the aggregate time series. The results in the original Jorgenson and Fraumeni paper are for 1982 and the aggregate time series lare from 1949-1984. Subsequent research by Christian (2012) developed modified JorgensonFraumeni $[(\mathrm{J}-\mathrm{F})$ human capital estimates from 1998 through 2009. Unfortunately there is a gap in coverage. Nonetheless, la comparison of the aggregates and their trends between the earlier and later period will be informative. The accounting tables in this new paper are for 2009, the latest base year for the NIPA accounts.
\end{abstract}

Barbara M. Fraumeni

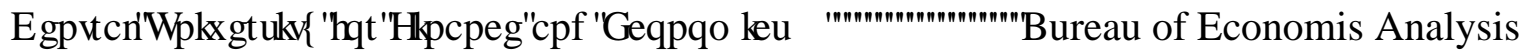

770 Middle Road

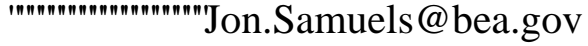

Dresden, ME 04342

and NBER

Barbara_Fraumeni@hotmail.com

Michael S. Christian

Wisconsin Center for Education Research

Madison, Wisconsin 53706

mchristian2@wisc.edu 


\title{
The Accumulation of Human and Nonhuman Capital, Revisited
}

\author{
Barbara M. Fraumeni, Michael S. Christian, and Jon D. Samuels
}

Just over twenty-five years ago, Jorgenson and Fraumeni (J-F) published their first paper on human capital (1989). This first paper emphasized the importance of human capital by presenting human capital estimates embedded in a complete national income accounting system. Since that time much has changed: the U.S. National Income and Product Accounts (NIPAs) have been substantially revised and the average number of years of formal schooling completed in the U.S. has increased by over fifty percent. In addition, increasing attention is being paid to the topic of human capital. The purpose of this paper is two-fold: 1) to integrate the J-F human capital accounts with an up-to-date and internally consistent system of national accounts, and 2) to describe changes and trends in the aggregates over time, particularly those related to human capital.

"Beyond GDP" is a catchword, popularized by the Stiglitz-Sen-Fitoussi Commission, which calls for innovation in economic accounts. Even before the final 2009 report was released, commission activities influenced related efforts and resulted in a workshop on human capital in Turin, Italy November 3-4 $4^{\text {th }}, 2008$. At this event, jointly organized by the OECD and the Fondazione Agnelli, Fraumeni (2008b) presented a paper which proposed a simplified approach to estimating Jorgenson-Fraumeni (J-F) human capital. Subsequently, the OECD Human Capital Project began with Gang Liu as the primary economist involved in estimating J-F-type human capital for 16 countries using a simplified approach. With that project, the number of countries with J-F human capital estimates increased from six to 18. Later, J-F estimates for Argentina and China were independently constructed as well as new estimates for the United States, bringing J-F country coverage to $20 .{ }^{1}$ Interest in human capital measurement continues to the present, with a report on OECD practices (OECD, 2012), a UNECE Task Force (Statistics Norway, 2014), and World Bank and UN reports on wealth (World Bank, 2010 and UNU-IHDP and UNEP, 2014), which both featured human capital.

Figure 1 shows how average educational attainment has changed at the five year frequency between 1950 and 2010 for three age groups: younger individuals aged 25-34, older individuals aged 55-64, and a broader age category for those aged 15-74 which includes the majority of the

\footnotetext{
${ }^{1}$ The countries include: Argentina, Australia, Canada, China, Denmark, France, Great Britain, India, Israel, Italy, Japan, the Netherlands, New Zealand, Norway, Poland, Rumania, South Korea, Spain, Sweden, and the United States. See Argentina (Coremberg, 2010), Australia (Wei, 2007, 2008), Canada (Gu and Wong, 2009), China (Li and co-authors 2009b, 2010a, 2014 and annual reports beginning in 2009), India (Gundimeda, Sanyal, Sinha, and Sukhdev, 2007), New Zealand (Le, Gibson, and Oxley, 2005), Norway (Liu and Greaker, 2009), Sweden (Ahlroth and Bjorkland, 1997), the United States (Christian, 2009, 2010, 2014) and Mira and Liu (2010) and Liu for the OECD human capital consortium countries (2011, 2014). O’Mahony and Stevens (2004) applied J-F methodology to evaluate government provided education in Great Britain. As the references above indicate, for several countries, OECD human capital project estimates exist as well as estimates constructed during the course of other research projects.
} 
adult population. ${ }^{2}$ In 1950 the difference in average educational attainment between the three age groups averaged around 1.5 years (6.7 years for those aged 55-64, 8.5 years for those aged 1574, and 9.9 years for those aged 25-34). By 2010 average educational attainment is almost identical across the three age groups, with the average for those aged 15-74 increasing from 8.5 to 13.2 years of formal schooling. The advances continued almost without abatement over the whole period, except for the oldest group during the 1980-1990 period; however the pace of these increases slowed after 2000. This paper traces through these changes in educational attainment that occurred over the last 25 years to their effects on human capital via the lifetime income approach.

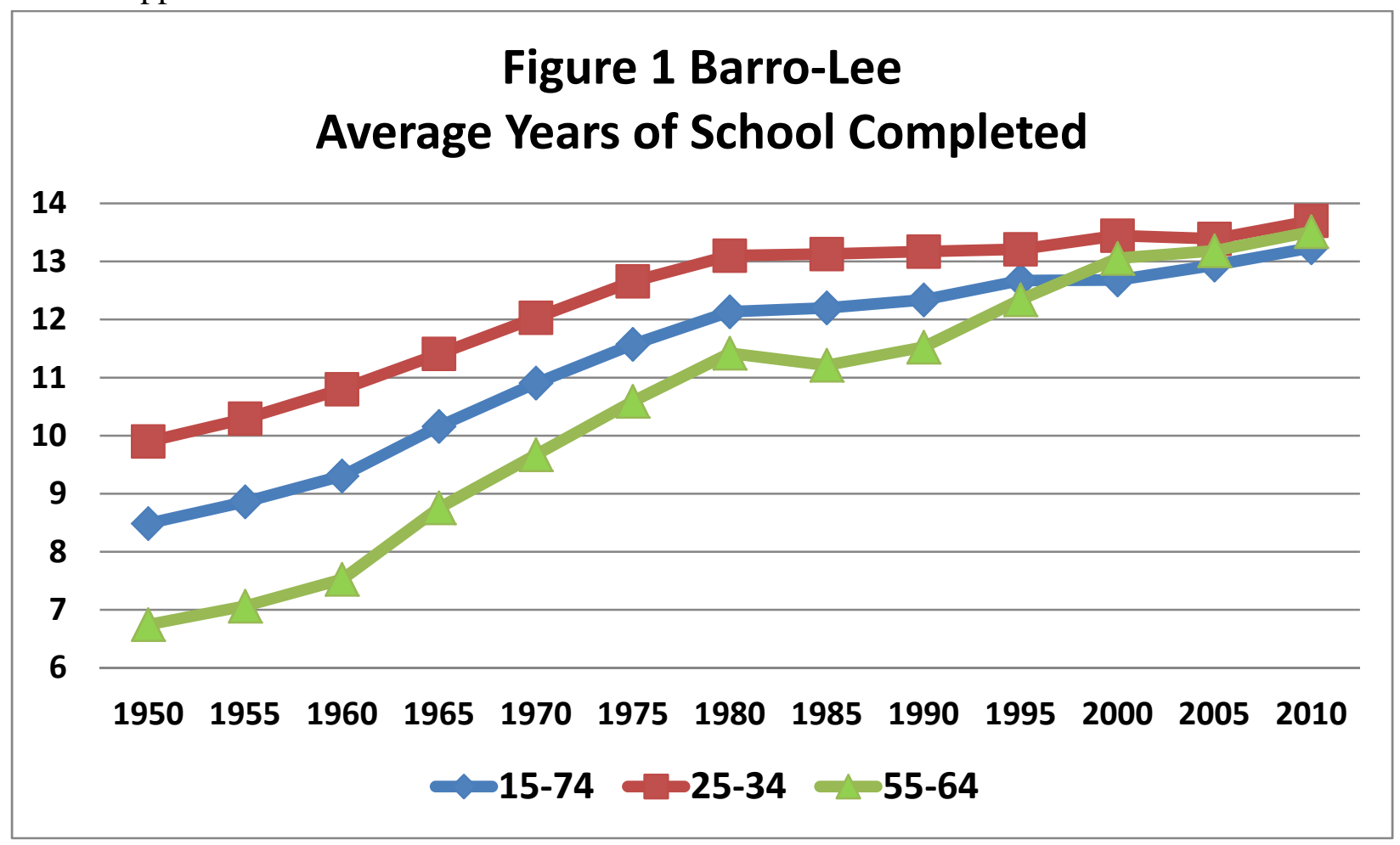

An important component of this paper is to integrate human capital estimates with a system of national accounts. Since the March 1986 data for the original 1989 paper was collected, six comprehensive NIPA revisions have occurred. There have been many definition, classification, source data, methodological, and presentation changes as a result of the revisions. Many were concerned with prices or quality change, such as hedonic price indexes for computers and implementation of chained Fisher ideal indexes. Other changes include the classification of software and research and development as investment, separation of government expenditures into consumption versus investment, measurement of implicit services provided by property and casualty insurance and by commercial banks, and a complete revamping of the table presentation

\footnotetext{
${ }^{2}$ See Barro and Lee 2013a and 2013b.
} 
of the accounts. ${ }^{3}$ In addition, the NIPAs changed to be in greater conformity with the System of National Accounts. ${ }^{4}$

This paper includes results for 1948 to 1984, the years covered in the original paper, and from 1998 to 2009, the years covered in the most recent paper by Christian. Human capital related estimates for 1948 to 1984 are identical to those in the original paper, but nonhuman estimates are for all years are updated. ${ }^{5}$

\section{Human Capital Accounts Methodology}

The Jorgenson-Fraumeni model of human capital (Jorgenson and Fraumeni, 1989, 1992b) measures human capital using the lifetime income approach. It measures the stock of human capital using an estimate of a population's lifetime earnings, current and future, in present discounted value. Investment in human capital captures the impact of events that have a positive impact on the human capital stock, such as births, formal education, and immigration. Depreciation of human capital captures the impact of events that have a negative impact on the human capital stock, such as deaths, aging, and emigration. Investment and depreciation--either in total, or for a particular reason such as education--are valued by the extent to which they add to or subtract from the human capital stock.

The lifetime income approach to measuring human capital (of which the Jorgenson-Fraumeni model is the most well-known example) is a commonly used approach to measuring human capital. Alternative approaches include the cost approach (Kendrick, 1976), which measures the stock of human capital using the cost of producing it, and the indicators approach, which measures human capital using indicators such as the average level of education, i.e. Barro and Lee (2013a). The J-F human capital approach integrates within the same conceptual framework as the national accounts.

The Jorgenson-Fraumeni model can be used to measure both a market and a nonmarket component of human capital. The market component of human capital is valued using lifetime market earnings. The nonmarket component is measured using an estimate of lifetime nonmarket time spent in activities other than market work, schooling, or personal maintenance, and valued using an opportunity cost equal to a tax-adjusted market wage. The JorgensonFraumeni model can also be used to measure human capital for an entire population (including children), or for a component of that population such as employed people or people of working age. Human capital for people of working age or for employed people is referred to as "active" human capital.

\footnotetext{
${ }^{3}$ See Boskin (2000) and various issues of the Survey of Current Business (U.S. Department of Commerce).

${ }^{4}$ For example, the term operating surplus was introduced during the 2003 comprehensive revision.

5 The updated nonhuman estimates are based on the May 28, 2014 NIPA tables.

${ }^{6}$ Estimates are not available for the middle period: 1985-1997. Constructing such estimates would require a multiyear full-time project because of the many steps required to do so and changes in the data sources.
} 
In the Jorgenson-Fraumeni model, the population is cross classified by age, sex, and education, and average lifetime earnings is the present discounted value of earnings. Estimates in a given year use average yearly earnings and school enrollment rates by age, sex, and education; discounted earnings reflect mortality rates by age and sex, and an assumed discount rate and skills-neutral income growth rate. Average yearly market earnings are set to post-tax labor income by age, sex, and education. Average yearly nonmarket earnings are set to the value of nonmarket time, defined as time not spent in market work, at school (assumed to be 1300 hours per year for enrolled persons), or in personal maintenance (assumed to be 10 hours per day for all persons). Nonmarket time is valued at the pre-tax market wage rate, multiplied by one minus the marginal tax rate to reflect the opportunity cost of leisure or household production. Age is topcoded at age 75, and levels of education reflect years of education from 0 (no education) to 18 (two years of graduate school or more).

The actual calculation of lifetime income begins at older ages, and then works its way back through younger ages. The model splits a lifetime into five stages. From ages 0 to 4, people do not attend school or earn income. From ages 5 to 13 (5 to 14 in the 1998-2009 results), people do not earn income, but may attend school. From ages 14 to 34 (15 to 34 in the 1998-2009 results), people may earn income and/or attend school. The differences in the ages between the phases in the earlier and later results reflects a change in the earliest age of labor income recorded in Census data. From ages 35 to 74, people no longer attend school, but continue to earn income. At age 75 or higher, people do not attend school or earn income.

For people age 75 and older, average lifetime earnings are assumed to be zero:

$$
i_{y, a, s, e}=0 \text { if } a=75+
$$

where $i_{y, s, a, e}$ is average lifetime income (market, nonmarket, or combined) in year $y$ for people of age $a$, sex $s$, and level of education $e$.

For ages 35 to 74, average lifetime earnings is equal to average current earnings, plus lifetime earnings at the next age older, adjusted for survival, discounting, and income growth:

$$
i_{y, a, s, e}=y i_{y, a, s, e}+\left[(1+\rho)^{-1}(1+g) s r_{y, a, s, e}\right] i_{y, a+1, s, e} \text { if } a=35,36, \ldots ., 74
$$

where $y i_{y, a, s, e}$ equals average yearly income (market or nonmarket) and $s r_{y, a, s, e}$ equals the survival rate in year $y$ for people of age $a$, sex $s$, and level of education $e$; $\rho$ equals the discount rate; and $g$ is the income growth rate. In the results presented here, the discount rate is set to 0.04, and the income growth rate is set to 0.02 as in the 1989 accumulation paper. Survival rates differ by age and sex, but are the same across levels of education within age and sex.

For ages 14 to 34 (15 to 34 in the 1998-2009 results), lifetime income estimates take into account the probability of attending school: 


$$
\begin{gathered}
i_{y, a, s, e}=y i_{y, a, s, e}+\operatorname{senr}_{y, a, s, e}\left[(1+\rho)^{-1}(1+g) s r_{y, a, s, e+1}\right] i_{y, a+1, s, e+1}+\left(1-\operatorname{sen}_{y, a, s, e}\right)\left[(1+\rho)^{-}\right. \\
\left.1(1+g) s r_{y, a, s, e}\right] i_{y, a+1, s, e} \quad \text { if } a=14,15, \ldots, 34
\end{gathered}
$$

where senr $r_{y, a+1, s, e}$ is the school enrollment rate in year $y$ of people of age $a$, sex $s$, and level of education $e$.

For ages 5 to 13 (5 to 14 in the 1998-2009 results), people are too young to earn income, and so yearly income is set to zero:

$$
\begin{aligned}
& i_{y, a, s, e}=\operatorname{sen}_{y, a, s, e}\left[(1+\rho)^{-1}(1+g) s r_{y, a, s, e+1}\right] i_{y, a+1, s, e+1}+\left(1-\operatorname{sen}_{y, a, s, e}\right)\left[(1+\rho)^{-1}(1+g) s r_{y, a, s, e}\right] i_{y, a+1, s, e} \\
& \text { if } a=5,6, \ldots ., 13
\end{aligned}
$$

and for ages 0 to 4, people are too young to attend school, so school enrollment rates are also set to zero:

$$
i_{y, a, s, e}=\left[(1+\rho)^{-1}(1+g) s r_{y, a, s, e+1}\right] i_{y, a+1, s, e} \quad \text { if } a=0,1, \ldots ., 4
$$

The stock of human capital in a given year is equal to the sum of lifetime income across a population, weighted by population by age, sex, and education:

$$
h c_{y}=\Sigma_{s} \Sigma_{a} \Sigma_{e}\left(p_{y, a, s, e} \times i_{y, a, s, e}\right)
$$

where $p_{y, a, s, e}$ is the population in year $y$ of people of age $a$, sex $s$, and level of education $e$. Note that this is computed using market, nonmarket, or combined lifetime income. It can also be computed using the entire population, or using a subset of the population (for example, people of working-age only).

Investment in human capital is measured using births, education, and (when available) immigration. Investment from births is the impact of births (the arrival of persons age 0 ) on the human capital stock, and is equal to

$$
b i_{y}=\Sigma_{s}\left(p_{y, 0, s, 0} \times i_{y, 0, s, 0}\right)
$$

Investment from education is the impact of education (people moving up from education level $e$ to education level $e^{+1}$ ) on the human capital stock, and is equal to

$$
s i_{y}=\Sigma_{s} \Sigma_{a} \Sigma_{e} \operatorname{senr}_{y, a, s, e}\left[p_{y, a, s, e} \times\left(i_{y, a, s, e+1}-i_{y, a, s, e}\right)\right]
$$

The 1998-2009 results include an additional component of investment, residual net investment. This is the impact of measured changes in the size and distribution of the population by sex, age, and education that cannot be attributed to measured births, deaths, or schooling. These changes exist for two reasons. The first is migration, which is not directly measured in the 1998-2009 results. The second is measurement error; in particular, the data on births, deaths, and educational attainment do not line up exactly with population estimates from year to year. The primary source of data for the 1998-2009 results are the March demographic and October school 
enrollment supplements to the Current Population Survey, adjusted to match published national aggregates for population, births, deaths, and enrollments, with survival rates from the Centers for Disease Control.

To measure human capital in real terms, the population $t$ (measured by age, sex, and education) is treated as the quantity, and the lifetime income component (similarly measured by age, sex, and education) is treated as the weight. ${ }^{7}$ The ratio of the nominal value to quantity index yield the implicit price.

\section{Overview of the Accounts}

This paper updates the original "accumulation” paper accounts, which were a comprehensive set of accounts that embedded human capital measures into modified NIPA accounts. The modified NIPA accounts were based on Christensen-Jorgenson (C-J) national income accounts (1973), which are summarized in Jorgenson (1980). Subsequently the C-J accounts were revised by a number of researchers working with Jorgenson: Stiroh, Landefeld, and Samuels, among others. The most recent and complete version of the modified NIPA accounts is described in Jorgenson and Landefeld (2006, 2009, and 2010). However, only the original “accumulation” paper added human capital measures to create "full" national account constructs based on the private domestic and private national economies. ${ }^{8}$ A purpose of this paper is to provide a fully integrated set of national accounts that includes human capital and is consistent with the concepts included in the US NIPAs.

The following figure briefly summarizes the five J-F accumulation paper accounts which are presented in more detail in a later section. Although the organization of the accounts is the same as in the original "accumulation" accounts, many individual elements of these accounts are revised to reflect the many national income accounting and tabular changes that have occurred since the publication of the original paper. For comparison, the detailed accounting tables presented later show data for 1982 (the base year in the original accumulation paper) and for 2009 (the current base year for the NIPA).

The complete accounting and integrated system with human capital measures in each account includes a production account, incorporating data on output and input; an income and expenditures account, giving data on income, expenditures, and saving; an accumulation account, allocating saving to various types of capital formation, and a balance sheet, containing data on private national wealth. The accumulation accounts are related to the wealth accounts through the accounting identity between period-to-period changes in wealth and the sum of net saving and the revaluation of assets.

\footnotetext{
7 The System of National Accounts term “volume” refers to the same concept as “quantity” as used in this paper.

8 The "new architecture” Jorgenson and Landefeld accounts (2006, 2009, and 2010) also include a foreign transactions current account and a U.S international position account.
} 


\section{Figure 2 Overview of the Five Accounts}

\section{PRODUCTION}

Full Gross Private Domestic Product equals Full Gross Private Domestic Factor Outlay
2. FULL PRIVATE NATIONAL LABOR \& GROSS NATIONAL PROPERTY INCOME

Full Private National Labor Income

Gross Private National Property Income

\section{FULL GROSS PRIVATE NATIONAL RECEIPTS \& EXPENDITURES}

Full Gross Private National Income

Full Private National Consumer Outlays plus Full Gross Private National Saving equals

Full Private National Consumer Expenditures

Full Gross Private National Consumer Receipts equals Full Private National Consumer Expenditures

\section{FULL GROSS PRIVATE NATIONAL CAPITAL ACCUMULATION}

Full Gross Private National Saving equals

Full Gross Private National Capital Formation

\section{FULL PRIVATE NATIONAL WEALTH}

Private National Nonhuman Wealth equals

Private Domestic Tangible Assets plus

Net Claims on Governments and the Rest-Of-The-Word

Private National Nonhuman plus Human Wealth equals

Full Private National Wealth 
The production account is for the private domestic economy; the other accounts use private national as the conceptual basis. The private domestic concept excludes the output and inputs of the government sector. The receipts and expenditure account is based on the accounting identity that the value of consumer receipts equals the value of outlays plus saving. Thus, compensation of government employees appears on the receipts side of the income and expenditure account. In general, the private national concept includes account relevant activities that occur in the United States, but restricts included relevant activities to those made by (such as expenditures), received by (such as income), or held by (such as wealth) private entities.

To give a sense of how relative magnitudes have changed over time, the figures 3 and 5-8 indicate the nominal dollar shares of the major components of the major aggregates included in the accounts in 1982 and 2009. ${ }^{9}$

Changes in the nominal shares of full gross private domestic product (see figure 2) between 1982 and 2009 mainly reflect changes in the labor force participation rate of women. Time in household production and leisure values time other than time in 1) sleep and maintenance (assumed to be 10 hours per day and given a zero valuation), 2) formal schooling (assumed to be 1300 hours per year for any enrolled individual), and 3) market work (which varies depending upon estimated hours). Time in household production and leisure is valued using the opportunity cost market wage. Human investment depends on the impact of births (a population increase) and formal schooling (increases in wages accrued to those with higher levels of education) on lifetime income, which includes both market and nonmarket income. As figure 4 illustrates, female labor force participation has almost doubled between 1948 and the end of the period, from just over 30 percent to around 60 percent. With the increase in female market work time, time spent and the corresponding nominal share of the value of time in household production and leisure in full gross private domestic product has decreased. Also, investment in education has risen between 1982 and 2009 with the higher educational attainment of both men and women, but most notably for women. ${ }^{10}$ At the same time, the nominal share of the "Full" component which is included in gross private domestic product has declined somewhat between 1982 and 2009.

\footnotetext{
${ }^{9}$ The "Full" aggregates include human capital accounts components.

${ }^{10}$ According to the Barro and Lee (2013b) estimates, in 2010 the percent of the total population aged 15 and above that completed the tertiary level of education is almost identical for females and males (both to two significant digits at 27 percent), however, females compared to males made the greatest gains in this category over the period from 1980 to 2010. In 1980, the percent of the female population aged 15 and above that completed the tertiary level of education was 14 percent; while for males it was 20 percent.
} 
Figure 3 Shares of

Full Gross Private Domestic Product 1982 and 2009

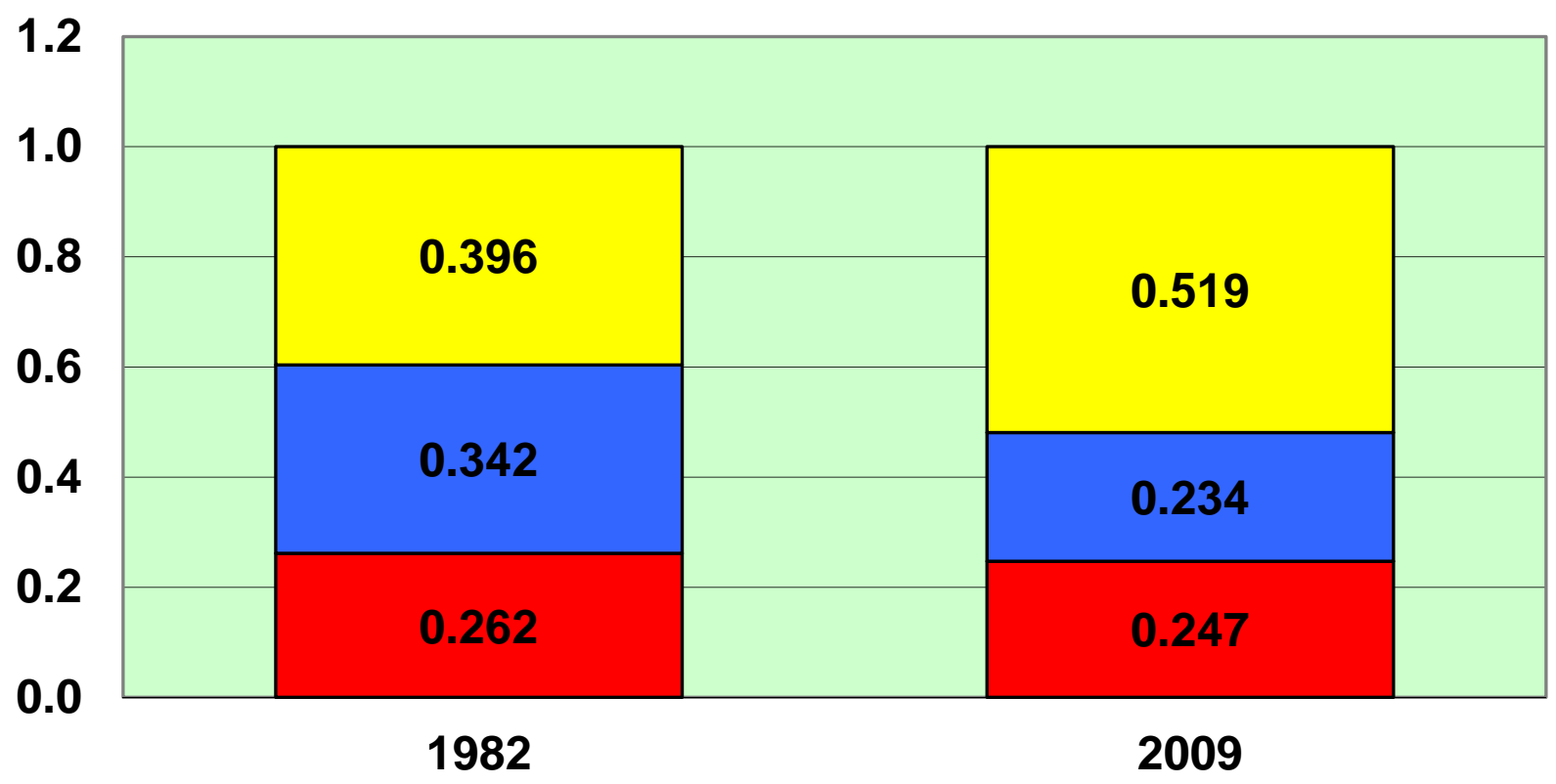

口Human investment

$\square$ Time in household production and leisure $\square$ Gross private domestic product

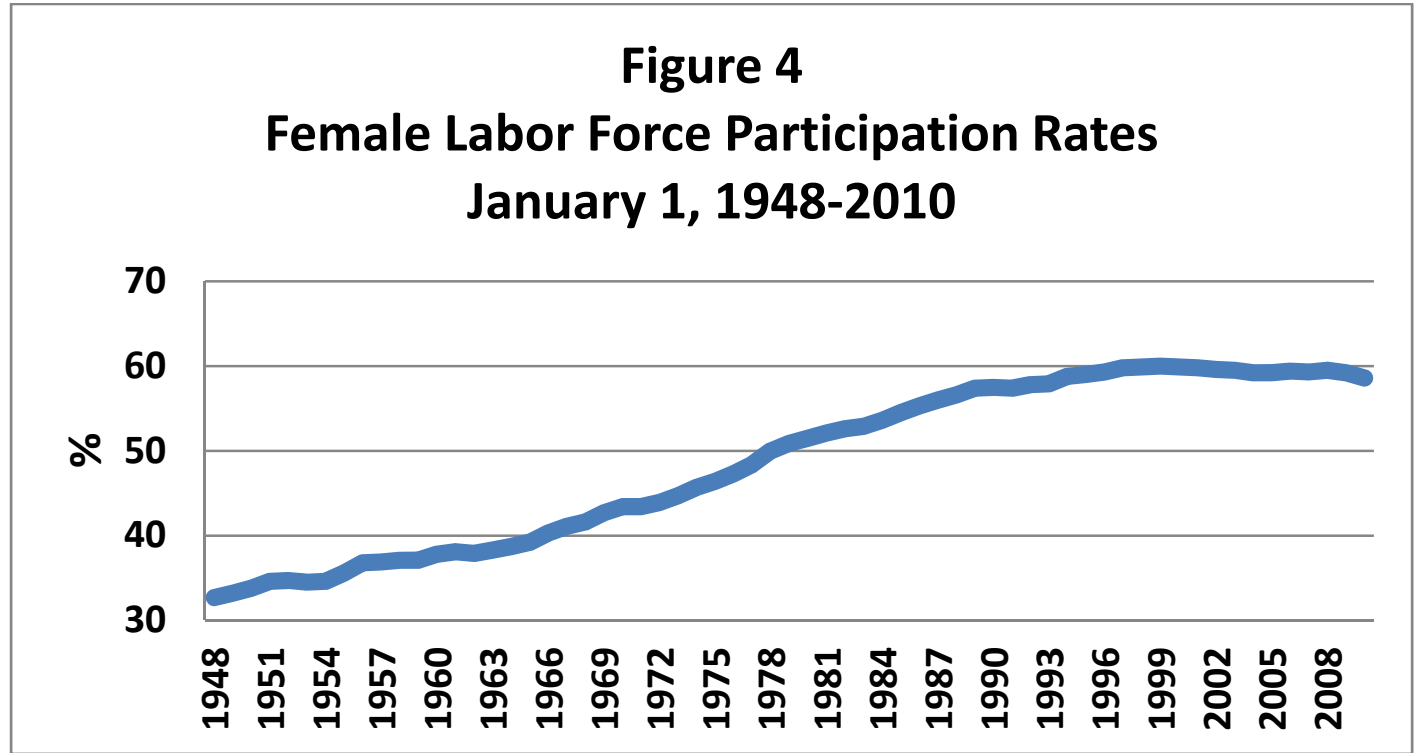


All of the major nominal subcomponents of gross private national income have increased by a factor of between 4.2 and 4.7 times between 1982 and 2009. The major subcomponents include private domestic outlay for labor services, private national labor income, nonmarket labor income, full private national labor income, gross domestic private outlay for capital services, and gross private national property income (see table 4). Gross private national property income (see figure 3) has stayed almost a constant nominal share of the sum of labor and property income. Note that nonmarket labor income includes both human investment and time in household production and leisure, so the trade-off between these two components of nonmarket labor income is masked in the aggregate shown in figure 3. The nominal share of the private (market) component of labor income has decreased slightly with a corresponding increase in the nonmarket component of labor income.

Figure 5

Shares of Full Private National Labor and Gross National Property Income 1982 and 2009

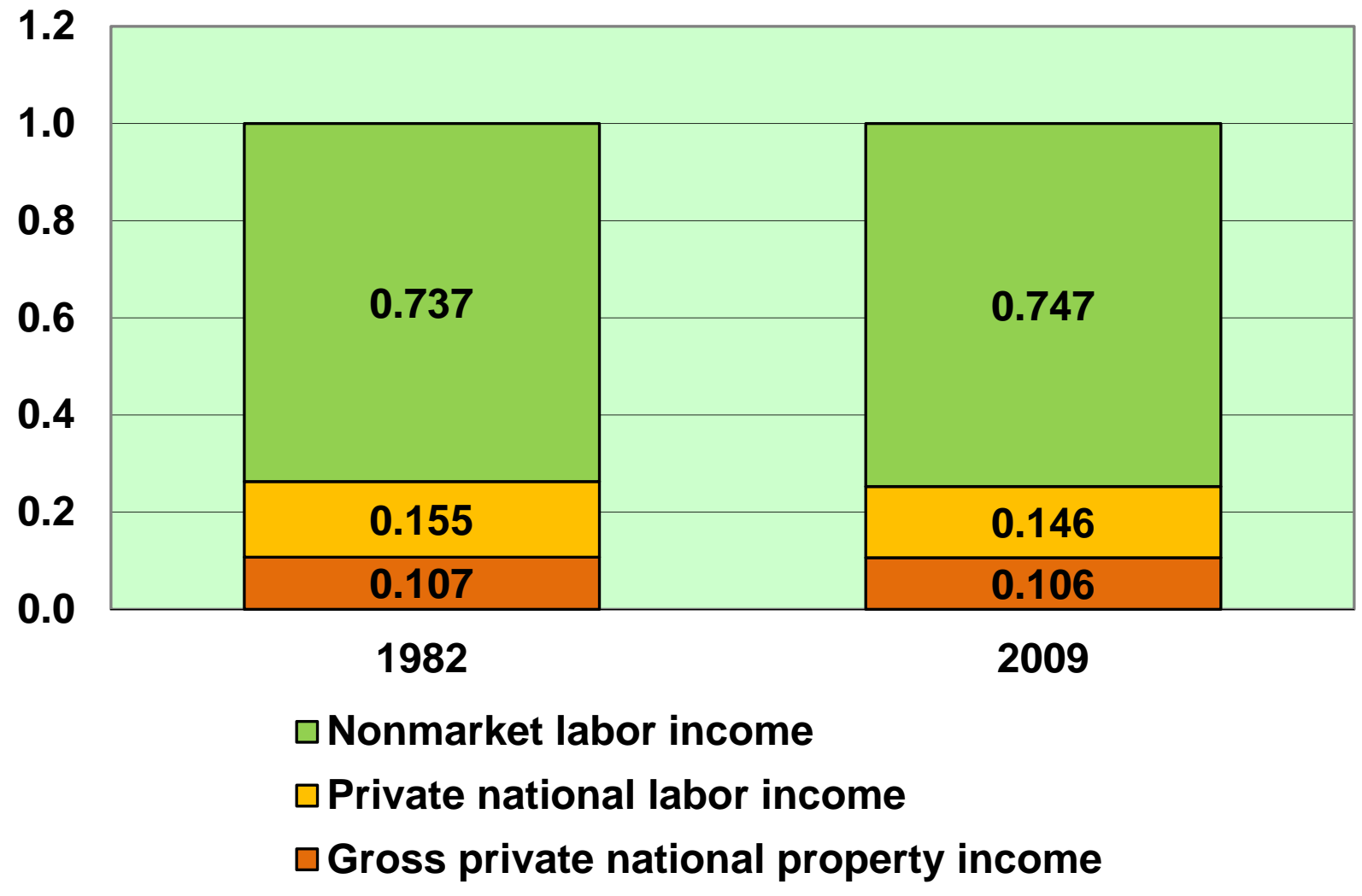


Overall the nominal share of capital formation in full private national consumer expenditures (see figure 6) has risen between 1982 and 2009. Often analysts are concerned about the level of private national capital formation, missing the important role that human capital formation has played since the early to mid-eighties. The nominal share of gross private national human capital formation in 1982 and full private national consumer outlays in 2009 are similar. The nominal share of full private national consumer outlays in1982 and gross private national human capital formation in 2009 are similar. The importance of including both human and private (nonhuman) capital formation is highlighted by this figure.

\section{Figure 6 Shares of Full Private National Consumer Expenditures \\ 1982 and 2009}

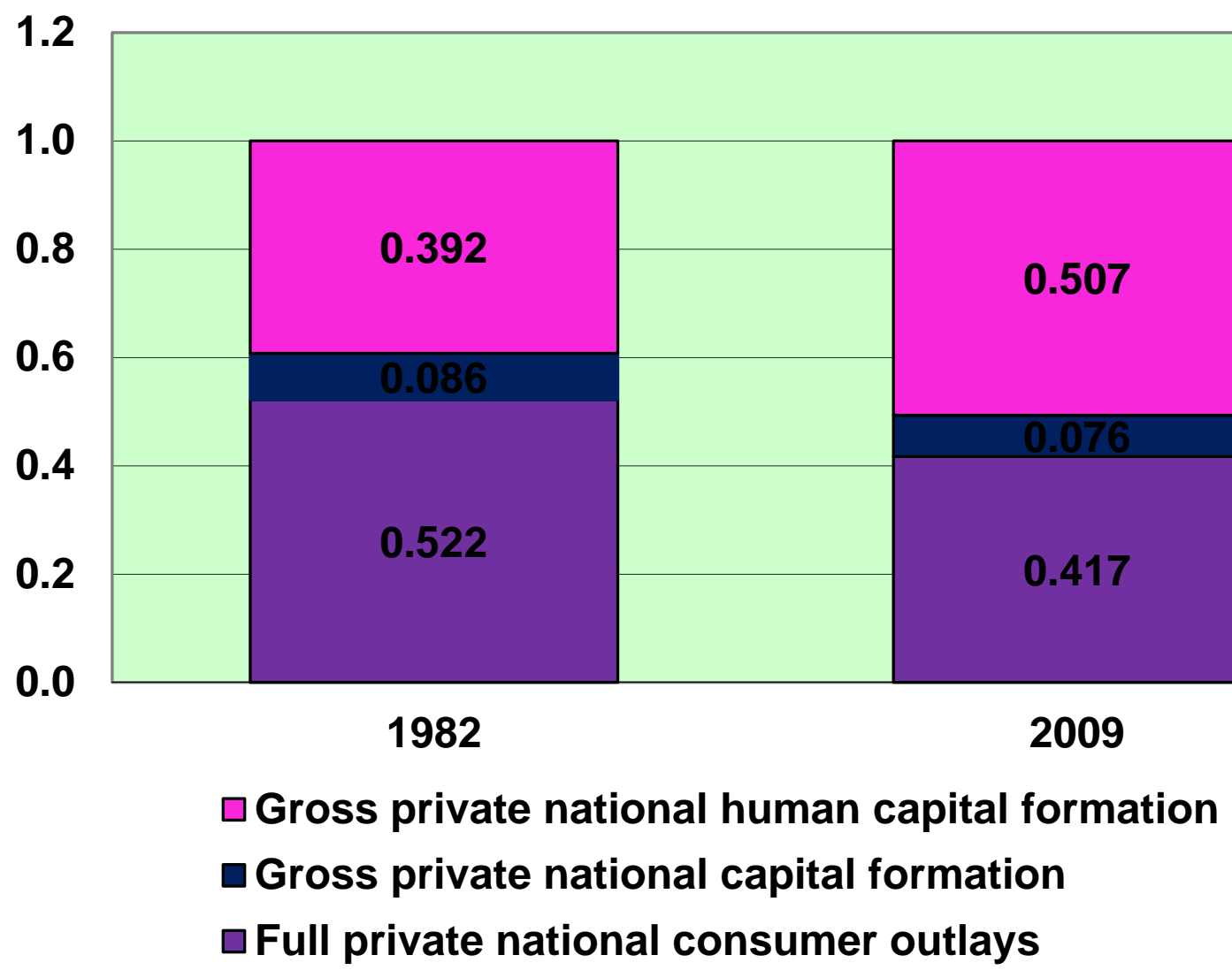


Human capital saving is clearly the largest, and a growing component of full gross private national saving (see figure 7). On average individuals have invested more in education since 1982. The increase in the average U.S. educational attainment is certainly in part a response to the demand for more highly skilled workers, which has resulted in a wage premium paid to those workers compared to those with fewer skills. ${ }^{11}$
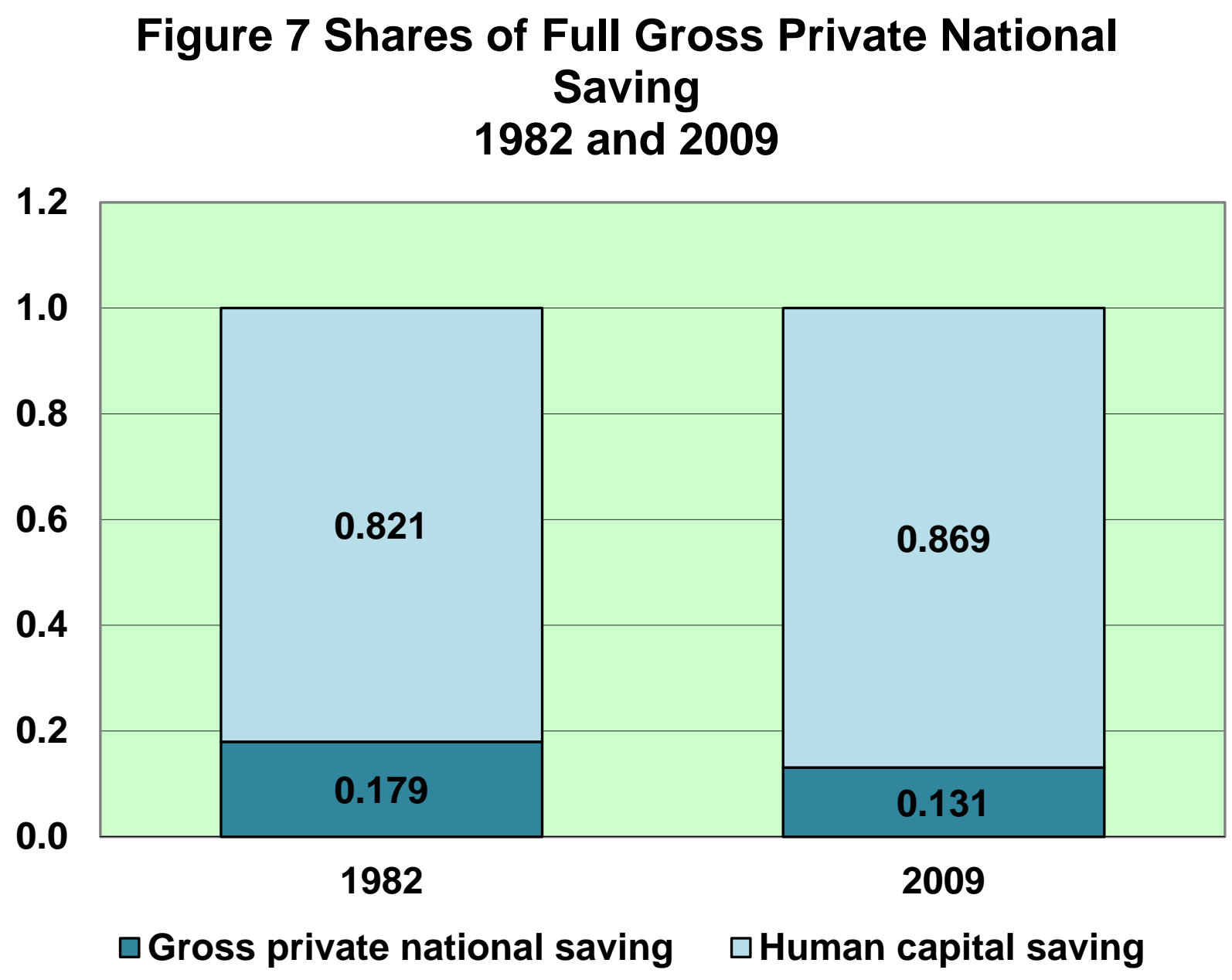

${ }^{11}$ See Figure 1 in Hotchkiss and Shiferaw (2014). 
It might be surprising that the nominal share of human wealth in full private national wealth has decreased over the same period, given the increase in the nominal share of human capital saving (see figure 8). This is likely due to the increase in depreciation as the baby-boomers approach retirement (Colby and Ortman, 2014). The nominal share of depreciation in full gross saving rose from 47 percent in 1982 to 80 percent in 2009 (see appendix table 19). The share of U.S.

resident population age 55 through age 64 rose from 9 percent in 1950, to 10 percent in 1980, and to 12 percent in 2010. ${ }^{12}$ Private national human wealth is by far the largest component of full private national wealth, accounting for over 90 percent of the nominal total in both years.

\section{Figure 8 Shares of Full Gross Private National Wealth 1982 and 2009}

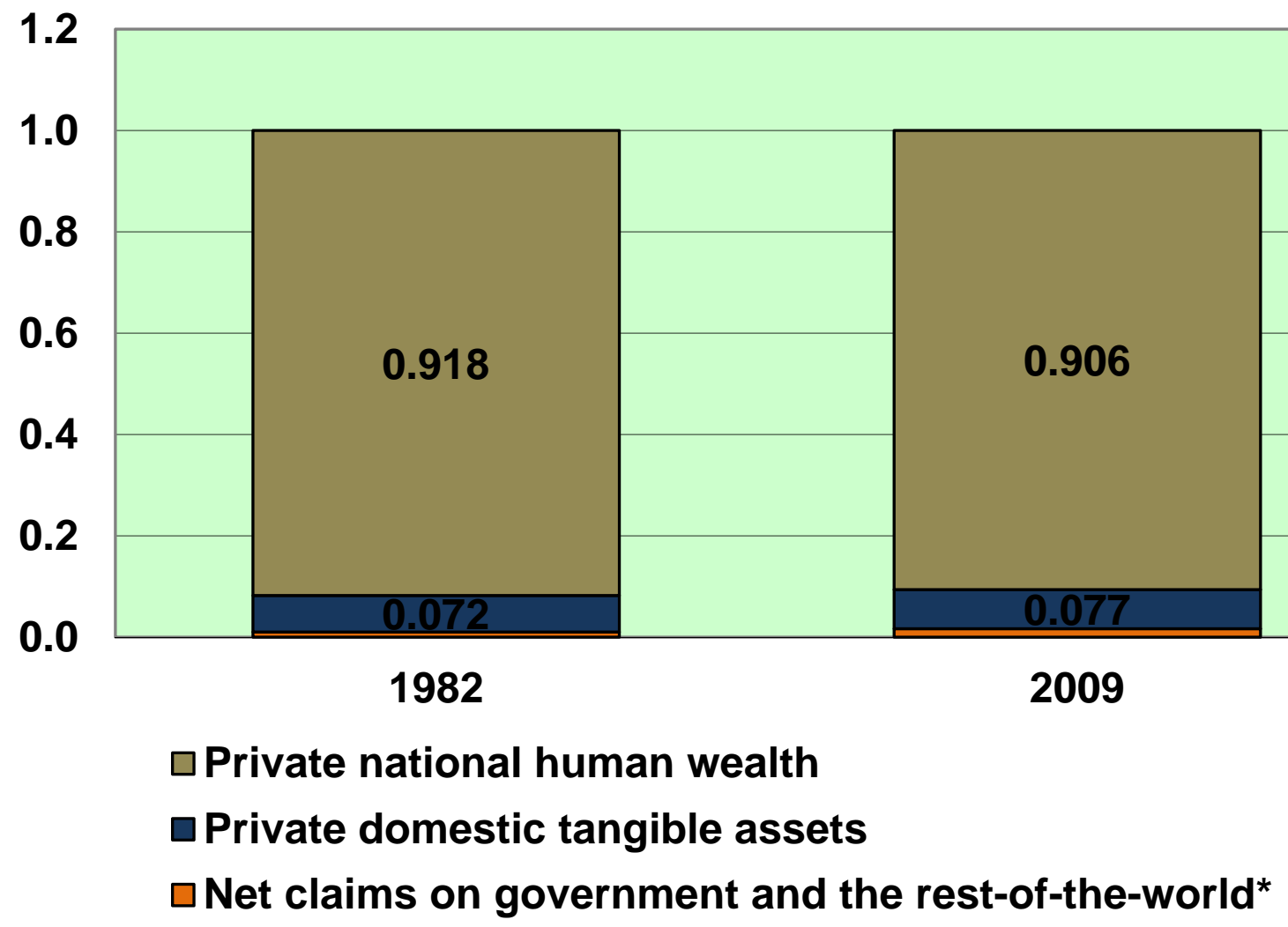

* The nominal shares for net claims on government and the rest-of-the-world are .0099 and .0164 for 1982 and 2009 respectively.

${ }^{12}$ U.S. Census Bureau, 2011, population table 7, and 1951, population projections by age and sex table no. 8. 


\section{Accounts Presentation and Discussion}

In this section, details of the accounts are presented in three ways with: 1) definitional tables for 1982 and 2009, 2) rates of growth tables for major aggregates by sub periods, and 3) contribution tables for major aggregates by sub periods. The rates of growth tables show rates of growth from 1949-1984, 1949-1973, 1973-1984, 1998-2009, 1998-2000, 2000-2005, and 2005-2009. The contributions tables, since contributions require lagged components, are for average contributions from 1950-1984, 1950-1973, 1974-1984, 1999-2009, 1999-2000, 2001-2005, and 2006-2009. As the original accumulation paper used Thornqvist indices, so does this updated and revised version. ${ }^{13}{ }^{14}$ With Thornqvist indices, contributions are a weighted rate of growth, where the weights are an average of the nominal dollar share in the previous period and the contemporaneous period and the rate of growth is a logarithmic growth rate of the quantities from the previous period to this period. The sub period breakpoints reflect economic conditions; in the productivity literature it has been clearly documented that productivity shifted downward post-1973; the period 1999-2000 corresponds to the end of the "IT Boom" period which began in 1995; and by 2006 the economy was headed towards the Great Recession (Jorgenson, Ho, and Samuels, 2104). Tables corresponding to all time series tables in the original accumulation paper are in the appendix; these time series tables are the data which underlie all figures and tables in the body of the paper. Accordingly, this paper provides a complete basis for review and analysis of the accounts presented herein which embed human capital related measures in a national income accounting framework.

The first account (see table 1 ) is the production account. ${ }^{15}$ As in the "new architecture" accounts (Jorgenson and Landefeld, 2006, 2009, and 2010), the core NIPA are modified in a number of ways. In the product account to allow for integration with productivity accounts, property-type taxes are included, but some other types of taxes such as primarily sales taxes, are not included. Imputations for nonhuman capital services (see line 16 of the product account) add into gross private domestic product several capital services that are not in NIPA GDP. These include those for consumer durables and real estate held by institutions and producer durable equipment held by institutions. The other imputation included in line 16 of the product account is for an addition to real estate held by households capital services as it is undercounted in NIPA GDP. These modifications are relatively minor in scale; as was already clearly seen in figure 3 , the human capital components dominate the production account.

For the sub periods that we consider, prices and quantities generally increase over time. For that reason and because the sum of the price and quantity rates of growth must equal the nominal dollar rate of growth, the rates of growth for quantities and prices are typically less than the rate

\footnotetext{
${ }^{13}$ Some of the sub components of the aggregates shown in this paper for the most recent period, 1998-2009, are constructed using Fisher indices. However, all aggregates in paper tables are constructed using Thornqvist indices.

${ }^{14}$ The human capital account components are identical to those in the original accumulation paper, but other components are revised over all periods to reflect changes and revisions in the NIPA.

${ }^{15}$ All table numbers in the account tables refer to NIPA table numbers unless otherwise specified.
} 


\begin{tabular}{|c|c|c|c|c|}
\hline \multicolumn{5}{|c|}{ Product } \\
\hline & & & 1982 & 2009 \\
\hline 1 & & Gross national product (table 1.7 .5 , line 4 ) & $3,381.5$ & $14,565.1$ \\
\hline 2 & - & Rest-of-world gross national product (table 1.7.5, line 2 minus line 3 ' & 36.5 & 147.2 \\
\hline 3 & - & $\begin{array}{l}\text { Compensation of government employees (table 6.2B, line } 76 \text { for 1982; table 6.2D, } \\
\text { line } 86 \text { for 2009) }\end{array}$ & 388.9 & $1,666.2$ \\
\hline 4 & - & Government consumption of fixed capital (table 5.1, line 17) & 113.9 & 442.7 \\
\hline 5 & $=$ & Gross private domestic product (NIPA definition) & $2,842.2$ & $12,309.0$ \\
\hline 6 & - & Federal taxes on production and imports (table 3.5 , line 2 ) & 41.0 & 91.4 \\
\hline 7 & - & Federal current transfer receipts from business (table 3.2, line 17 & 3.7 & 46.7 \\
\hline 8 & + & Capital stock tax (table 3.5 , line 12 ) & 0.0 & 0.0 \\
\hline 9 & - & State and local taxes on production and imports (table 3.5 , line 13' & 200.0 & 934.8 \\
\hline 10 & - & State and local current transfer receipts from business (table 3.3, line 18 & 3.2 & 44.0 \\
\hline 11 & + & Business property taxes (table 3.5 , line 27 ) & 85.3 & 435.1 \\
\hline 12 & + & Business motor vehicle licenses (table 3.5 , line 28) & 2.1 & 8.7 \\
\hline 13 & + & Business other taxes (table 3.5 , sum of lines 29-31) & 16.4 & 67.2 \\
\hline 14 & + & $\begin{array}{l}\text { Subsidies less current surplus of federal government enterprises (table 3.2, line } 32 \\
\text { minus line 19) }\end{array}$ & 16.7 & 56.1 \\
\hline 15 & + & $\begin{array}{l}\text { Subsidies less current surplus of state and local government enterprises (table } 3.3 \\
\text { line } 25 \text { minus line 20) }\end{array}$ & 2.2 & 22.8 \\
\hline 16 & + & Imputations for nonhuman capital services & 298.9 & $1,234.6$ \\
\hline 17 & $=$ & Gross private domestic product & $3,015.9$ & $13,016.6$ \\
\hline 18 & + & Time in household production and leisure & $3,944.5$ & $12,311.0$ \\
\hline 19 & + & Investment in human capital, births* & $2,184.7$ & $9,551.5$ \\
\hline 20 & + & Investment in human capital, education* & $2,383.9$ & $15,955.0$ \\
\hline 21 & + & Investment in human capital, residual & 0.0 & $1,841.2$ \\
\hline \multirow[t]{3}{*}{22} & $=$ & Full gross private domestic product & $11,529.0$ & $\overline{52,675.4}$ \\
\hline & \multicolumn{4}{|c|}{ Factor Outlay } \\
\hline & & & 1982 & 2009 \\
\hline 1 & & $\begin{array}{l}\text { Compensation of employees, all private industries (table } 6.2 \mathrm{~B} \text { for } 1982 \text { and } \\
\text { table } 6.2 \mathrm{D} \text { for 2009, both line 3) }\end{array}$ & $1,505.6$ & $6,129.5$ \\
\hline 2 & + & Entrepreneurial labor income (imputation) & 162.6 & 828.9 \\
\hline 3 & + & $\begin{array}{l}\text { Full property outlay (line } 17 \text { from the Product account, minus lines } 1 \text { and } 2 \text { from the } \\
\text { factor outlay account) }\end{array}$ & $1,347.6$ & $6,058.2$ \\
\hline 4 & $=$ & Gross private domestic factor outlay & $3,015.9$ & $13,016.6$ \\
\hline 5 & + & Imputations for human capital services from product account above (lines 18-21) & $8,513.1$ & $39,658.7$ \\
\hline 6 & $=$ & Full gross private domestic factor outlay & $11,529.0$ & $52,675.4$ \\
\hline
\end{tabular}

Note: Totals may differ slightly from the sums due to rounding

* The split between birth and education in 1982 is imputed from a somewhat later version of the accounts presentec

in the original accumulation paper. Accordingly, this is the only place in this paper where this split is shown 
of growth of nominal dollars. ${ }^{16}$ Because quantities per capita are divided by a population denominator that is always growing throughout the period, the rate of growth of the quantity is always greater than the rate of growth of the quantity per capita. Discussion will focus on the price and quantity subcomponents of the nominal dollar rate of growth and on the quantities per capita.

By sub periods, with one exception, the full product, full investment and full consumption price rates of growth are always greater than the quantity rates of growth (see table 2). ${ }^{17}$ Both full investment and full consumption encompass human capital related components; the former includes human capital investment (births and education) and the latter includes time in household production and leisure. Between the earlier period (1948-1984) and the later period (1998-2009), the nominal share of full investment in full product becomes larger than the nominal share of full consumption in full product (see appendix table 3). By sub periods, full investment prices, which grow at a higher rate than full consumption prices in the earlier period, grow at a lower rate than full consumption prices in the later period, with the exception of 19982000. However, in all sub periods except for 1949-1973, full consumption quantities and quantities per capita (shown in the constant prices per capita line) grow at a higher rate than full investment quantities. ${ }^{19}$ However, in 1949-1973, the difference between the rates of growth is only .001 percentage point. Full investment quantities per capita decrease in all sub periods beginning in 1973 or after. Population growth averaged about 1 percent per year during that time period. The quantity of human capital investment increase only slightly between 1973 and 1984 and actually decreased between 1998 and 2009 (see appendix table 2). ${ }^{20}$

By sub periods, full property outlay quantities and quantities per capita always grow at a much faster rate than full labor outlay quantities and quantities per capita (see table 3). The decline in quantities per capita in all of the later sub periods again reflects the slowdown in human capital investment growth, which is included in full labor outlay. This decline is offset slightly by the

\footnotetext{
${ }^{16}$ By logarithmic rules, the log of a product is equal to the sum of the log of each component of the product.

${ }^{17}$ Nonhuman consumption and investment is constructed from the producer point of view.

${ }^{18}$ In the original accumulation paper, the term "current prices" was used to refer to nominal dollars, the term "constant prices" was used to refer to quantity, and the term "price index" was used to refer to price.

${ }^{19}$ United States national population grew at a rate of .0131 in 1949-1984, .0146 in 1949-1973, .0097 in 1973-1984, .0915 in 1998-2009, .0216 in 1998-2000, .092 in 2000-2005, and .0093 in 2005-2009. The population figures from 2000-2009 are intercensul estimates, which means that the change between 1999 and 2000 is expected to be revised eventually. The one year growth rate between 1999 and 2000 is .0341. Accordingly, all quantity per capita growth estimates for 1998-2000 are likely biased downward. Subsequent sub period growth rates are also impacted, but to a significantly lesser degree.

${ }^{20}$ Population data was collected on January 11, 2015 from the U.S. Bureau of the Census website. See U.S. Bureau of the Census (undated, 2000). July 1 population estimates are used in this paper.
} 
increase in the quantity of time in household production and leisure. ${ }^{21}$ As figure 1 shows, the gains in average educational attainment slowed during this later time period.

Table 2 Full Gross Private Domestic Product, rates of growth, 1949-1984, 1998-2009

\begin{tabular}{lccccccc}
\hline & $1949-$ & $1949-$ & $1973-$ & $1998-$ & $1998-$ & $2000-$ & $2005-$ \\
& 1984 & 1973 & 1984 & 2009 & 2000 & 2005 & 2009 \\
\hline Full product: & & & & & & & \\
$\quad$ Nominal dollar & 0.0732 & 0.0673 & 0.0861 & 0.0307 & 0.0515 & 0.0193 & 0.0345 \\
Quantity & 0.0220 & 0.0244 & 0.0167 & 0.0081 & 0.0175 & 0.0055 & 0.0067 \\
Quantity per capita & 0.0089 & 0.0098 & 0.0070 & -0.0034 & -0.0040 & -0.0038 & -0.0026 \\
Price & 0.0513 & 0.0429 & 0.0694 & 0.0226 & 0.0341 & 0.0139 & 0.0277 \\
Full investment: & & & & & & & \\
Nominal dollar & 0.0732 & 0.0695 & 0.0811 & 0.0197 & 0.0525 & 0.0040 & 0.0228 \\
Quantity & 0.0198 & 0.0245 & 0.0095 & -0.0007 & 0.0127 & -0.0042 & -0.0030 \\
Quantity per capita & 0.0067 & 0.0098 & -0.0002 & -0.0122 & -0.0088 & -0.0135 & -0.0124 \\
Price & 0.0537 & 0.0456 & 0.0713 & 0.0199 & 0.0389 & 0.0079 & 0.0255 \\
Full consumption: & & & & & & & 0.0516 \\
Nominal dollar & 0.0733 & 0.0652 & 0.0909 & 0.0484 & 0.0496 & 0.0454 & 0.025 \\
Quantity & 0.0242 & 0.0244 & 0.0237 & 0.0227 & 0.0266 & 0.0222 & 0.0214 \\
Quantity per capita & 0.0111 & 0.0098 & 0.0140 & 0.0112 & 0.0050 & 0.0129 & 0.0120 \\
Price & 0.0492 & 0.0409 & 0.0672 & 0.0258 & 0.0234 & 0.0232 & 0.0303 \\
\hline
\end{tabular}

\footnotetext{
${ }^{21}$ The quantity of time in household production and leisure is shown in appendix table 14 under the title "nonmarket consumer outlays."
} 
Table 3 Gross Private National Labor and Property Income, rates of growth, 1949-1984, 1998-2009

\begin{tabular}{lccccccc}
\hline & $1949-$ & $1949-$ & $1973-$ & $1998-$ & $1998-$ & $2000-$ & $2005-$ \\
& 1984 & 1973 & 1984 & 2009 & 2000 & 2005 & 2009 \\
\hline Full factor outlay: & & & & & & & \\
Nominal dollar & 0.0732 & 0.0673 & 0.0861 & 0.0307 & 0.0515 & 0.0193 & 0.0345 \\
Quantity & 0.0191 & 0.0206 & 0.0158 & 0.0062 & 0.0135 & 0.0024 & 0.0074 \\
Quantity per capita & 0.0060 & 0.0059 & 0.0061 & -0.0053 & -0.0081 & -0.0069 & -0.0020 \\
Price & 0.0541 & 0.0467 & 0.0703 & 0.0245 & 0.0378 & 0.0170 & 0.0272 \\
Full labor outlay: & & & & & & & \\
Nominal dollar & 0.0723 & 0.0673 & 0.0831 & 0.0284 & 0.0537 & 0.0152 & 0.0323 \\
Quantity & 0.0170 & 0.0185 & 0.0136 & 0.0031 & 0.0100 & -0.0010 & 0.0049 \\
Quantity per capita & 0.0039 & 0.0039 & 0.0039 & -0.0084 & -0.0116 & -0.0103 & -0.0044 \\
Price & 0.0553 & 0.0488 & 0.0694 & 0.0253 & 0.0436 & 0.0163 & 0.0275 \\
Full property outlay: & & & & & & & 0.0520 \\
Nominal dollar & 0.0810 & 0.0674 & 0.1105 & 0.0501 & 0.0297 & 0.0566 & 0.0520 \\
Quantity & 0.0372 & 0.0387 & 0.0339 & 0.0345 & 0.0482 & 0.0351 & 0.0268 \\
Quantity per capita & 0.0241 & 0.0241 & 0.0241 & 0.0229 & 0.0266 & 0.0259 & 0.0174 \\
Price & 0.0438 & 0.0287 & 0.0766 & 0.0156 & -0.0181 & 0.0215 & 0.0252 \\
\hline
\end{tabular}


The first contribution figure (see figure 9) presents both sides of the production account as well as the implied multifactor productivity growth that is consistent with full product output and inputs. ${ }^{22}$ Even with human capital measures integrated into the account, as expected multifactor productivity growth falls beginning in the 1974-1984 sub period, recovers strongly in 1999-2000, but falls again, and even becomes negative, during the last period, 2006-2009, which includes the Great Recession and the slow recovery. Except during the 1950-1973 sub period, the contribution of full consumption to overall economic growth outweighs that of full investment. Except during the 1999-2009 and 2001-2005 sub periods, the contribution of full labor to economic growth outweighs that of full capital. The negative contribution of full labor in 20012005, which dominates the 1999-2009 period, is due to the factor mentioned earlier: the slowdown in human capital investment. Full capital contributes more to economic growth than multifactor productivity growth in all periods.

The second account is the labor and property income account (see table 4). Human capital components only enter into labor income. Figure 5 showed that there is very little change in the nominal share of gross private national labor income in total income between 1982 and 2009 and that nonmarket labor income represents almost 75 percent of total income. In this account, the split of personal income taxes between labor and property income is imputed in the modified NIPA set of accounts.

By sub period, full private national labor income growth demonstrates a typical pattern for a labor aggregate, but there is no consistent growth pattern for gross private national property income in the earlier sub periods (see table 5). For labor income, the growth in prices is consistently greater than the growth in quantities and the growth in quantities is consistently greater than the growth in quantities per capita as expected. The growth in property income quantities is greater than growth in prices for only two of the seven sub periods: 1949-1984 and 1973-1984. The growth in prices for each of the three aggregates in all later period sub periods is always less than the growth in prices in all of the earlier period sub periods.

The third account is the consumer receipts and expenditures account (see table 6). The aggregate full gross private national saving includes human saving as well as nonhuman saving (see appendix table 15 and line 10 of the Expenditures part of the account). The receipts part of the account includes all human capital components listed in the Product account of table 1. Consumer durables are excluded from expenditures as in the modified "new architecture" accounts and these accounts as consumer durables are considered investment (see line 2 of the Expenditures part of the account). Figure 6 showed that there is a very large increase in the nominal share of gross private national human capital formation in full private national consumer expenditures between 1982 and 2009.

\footnotetext{
${ }^{22}$ Some titles are truncated in figure 9 because of space considerations.
} 
Figure 9 Contributions to Full Gross Private Domestic Product and Economic Growth

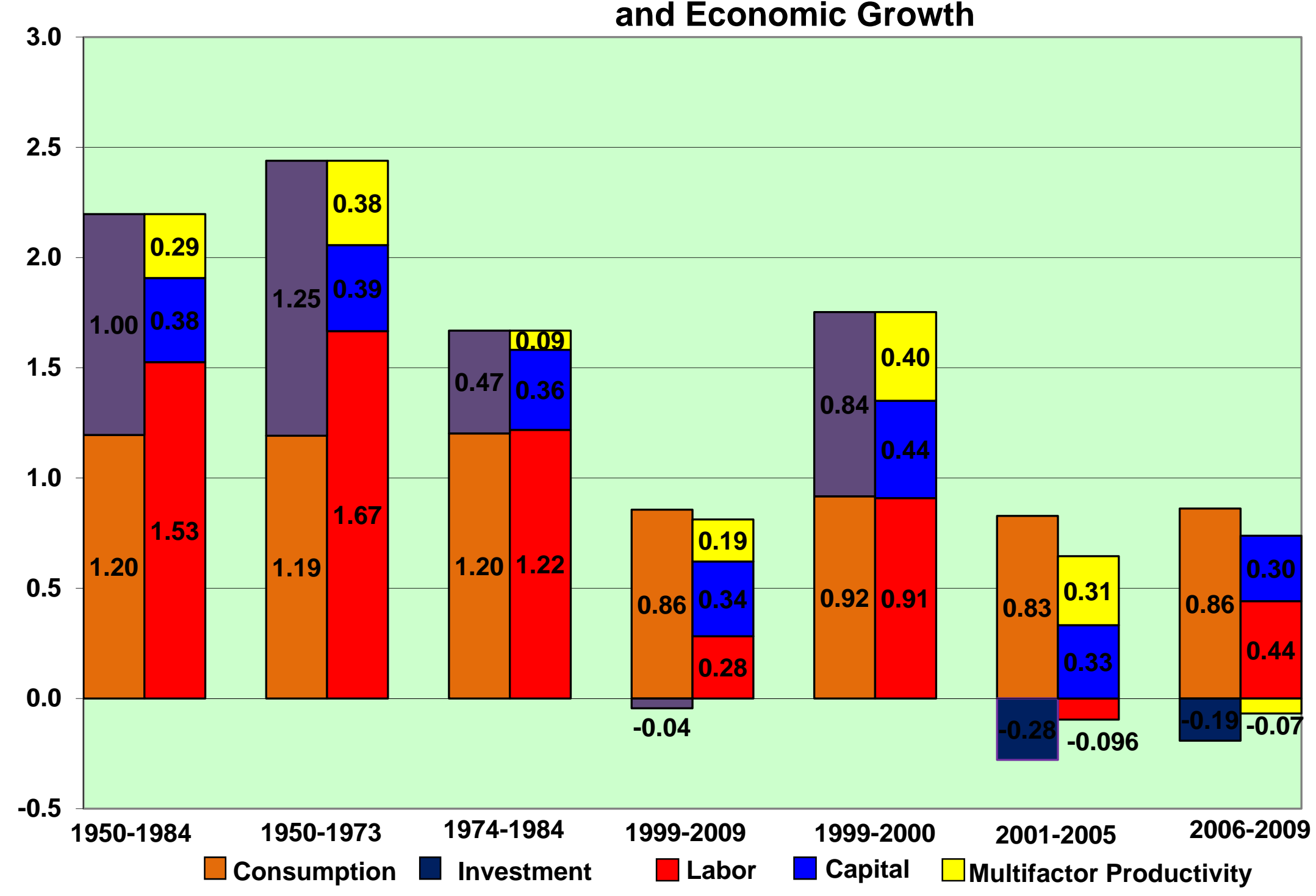


Table 4 Full Private National Labor and Gross Private National Property Income, United States, 1982 and 2009 (billions of dollars)

\begin{tabular}{|c|c|c|c|c|}
\hline \multicolumn{5}{|c|}{ Labor Income } \\
\hline & & & 1982 & 2009 \\
\hline 1 & & $\begin{array}{l}\text { Private domestic outlay for labor services (line } 1 \text { plus line } 2 \text { of the Factor Outlay } \\
\text { account in table 1) }\end{array}$ & $1,668.2$ & $6,958.4$ \\
\hline 2 & + & Income originating in general government (table 1.13, line 56) & 346.8 & $1,517.4$ \\
\hline 3 & + & Compensation of employees in government enterprises (table 1.13, line 37 ) & 42.1 & 148.8 \\
\hline 4 & + & Compensation of employees, rest-of-world (table 1.13, line 61) & -0.2 & -7.8 \\
\hline 5 & - & Personal income taxes attributed to labor income (imputation) & 261.9 & 843.1 \\
\hline 6 & $=$ & Private national labor income & $1,795.0$ & $7,773.7$ \\
\hline 7 & + & Nonmarket labor income (sum of lines $18-21$ of the Product account in table 1 ) & $8,513.1$ & $39,658.7$ \\
\hline 8 & $=$ & Full private national labor income & $10,308.1$ & $47,432.4$ \\
\hline \multicolumn{5}{|c|}{ Property Income } \\
\hline & & & 1982 & 2009 \\
\hline 1 & & Gross domestic private outlay for capital services (imputation) & $1,347.5$ & $6,058.1$ \\
\hline 2 & + & Capital income originating in the rest-of-world (imputation) & 36.5 & 155.0 \\
\hline 3 & + & Personal interest income (table 2.1, line 14) & 463.7 & $1,263.9$ \\
\hline 4 & - & Net interest and miscellaneous payments on assets (table 1.7.5, line 20) & 277.5 & 563.1 \\
\hline 5 & + & Government rents and royalties (table 3.2 , line 15 plus table 3.3 , line 15 ) & 8.6 & 18.2 \\
\hline 6 & - & Personal interest payments to business (table 2.1 , line 30 ) & 59.3 & 273.9 \\
\hline 7 & + & $\begin{array}{l}\text { Investment income of social insurance funds less transfers to general government } \\
\text { (table } 3.14 \text {, line } 8 \text { plus line } 22 \text {, minus lines } 11 \text { and } 24 \text { ) }\end{array}$ & 1.9 & 123.8 \\
\hline 8 & + & $\begin{array}{l}\text { Rest-of-world contributions to government social } \\
\text { insurance (table } 3.6 \text {, line } 32 \text { ) }\end{array}$ & 1.2 & 5.0 \\
\hline 9 & - & Corporate profits tax liability (table 3.2 line 7 plus table 3.3 line 10 ) & 63.0 & 246.0 \\
\hline 10 & - & Personal property taxes(table 3.4 , sum of lines 18,19 , and 20 ) & 7.3 & 28.2 \\
\hline 11 & - & Business property taxes (line 4 from this paper's Factor Outlay account in table 1 ) & 103.8 & 511.0 \\
\hline 12 & - & Personal income taxes attributed to property income (imputation) & 85.0 & 273.6 \\
\hline 13 & - & Federal estate and gift taxes (table 5.11, line 19) & 7.5 & 20.6 \\
\hline 14 & - & State and local estate and gift taxes (table 5.11, line 20) & 2.6 & 4.3 \\
\hline 15 & - & Business transfer payments to foreigners (table 4.1 , line 28 ) & 3.4 & 21.2 \\
\hline 16 & - & Rents and royalties received by the Federal government (table 3.2 , line 15 ) & 5.1 & 7.0 \\
\hline 17 & - & Rents and royalties received by state and local governments (table 3.3 , line 15 ) & 3.5 & 11.2 \\
\hline 18 & - & Dividends received by government (table 3.1 , line 10 ) & 0.2 & 20.9 \\
\hline 19 & $=$ & Gross private national property income & $1,241.2$ & $5,643.1$ \\
\hline
\end{tabular}

Note: Totals may differ slightly from the sums due to rounding. 
Table 5 Full Private National Income, rates of growth, 1949-1984, 1998-2009

\begin{tabular}{lccccccc}
\hline & $1949-$ & $1949-$ & $1973-$ & $1998-$ & $1998-$ & $2000-$ & $2005-$ \\
& 1984 & 1973 & 1984 & 2009 & 2000 & 2005 & 2009 \\
\hline Full national income: & & & & & & & \\
$\quad$ Nominal dollar & 0.0734 & 0.0675 & 0.0864 & 0.0320 & 0.0503 & 0.0204 & 0.0373 \\
Quantity & 0.0193 & 0.0205 & 0.0167 & 0.0072 & 0.0119 & 0.0025 & 0.0108 \\
Quantity per capita & 0.0062 & 0.0059 & 0.0070 & -0.0043 & -0.0097 & -0.0068 & 0.0014 \\
Price & 0.0541 & 0.0470 & 0.0697 & 0.0247 & 0.0379 & 0.0179 & 0.0266 \\
Full labor income: & & & & & & & \\
Nominal dollar & 0.0723 & 0.0675 & 0.0827 & 0.0296 & 0.0529 & 0.0170 & 0.0336 \\
Quantity & 0.0173 & 0.0189 & 0.0138 & 0.0041 & 0.0096 & -0.0005 & 0.0071 \\
Quantity per capita & 0.0042 & 0.0043 & 0.0041 & -0.0074 & -0.0120 & -0.0098 & -0.0023 \\
Price & 0.0550 & 0.0485 & 0.0689 & 0.0254 & 0.0431 & 0.0174 & 0.0266 \\
Full property income: & & & & & & & \\
Nominal dollar & 0.0839 & 0.0670 & 0.1208 & 0.0552 & 0.0195 & 0.0575 & 0.0700 \\
Quantity & 0.0401 & 0.0382 & 0.0443 & 0.0394 & 0.0375 & 0.0360 & 0.0446 \\
Quantity per capita & 0.0270 & 0.0236 & 0.0346 & 0.0279 & 0.0159 & 0.0267 & 0.0353 \\
Price & 0.0438 & 0.0288 & 0.0764 & 0.0158 & -0.0180 & 0.0216 & 0.0254 \\
\hline
\end{tabular}




\begin{tabular}{|c|c|c|c|c|}
\hline \multicolumn{5}{|c|}{ Receipts } \\
\hline & & & 1982 & 2009 \\
\hline 1 & & Gross private domestic factor outlay (line 4 of the Factor Outlay account of table 1 ) & $3,015.9$ & $13,016.6$ \\
\hline 2 & + & Income originating in rest-of-world (table 6.1 , line 82 ) & 36.5 & 147.2 \\
\hline 3 & + & Compensation of employees in general government and government enterprises & 388.9 & $1,666.2$ \\
\hline 4 & + & $\begin{array}{l}\text { Investment income of social insurance funds less transfers to general government } \\
\text { (table } 3.14 \text {, line } 8 \text { plus line } 22 \text {, minus lines } 11 \text { and } 24 \text { ) }\end{array}$ & 1.9 & 123.8 \\
\hline 5 & + & Rest-of-world contributions to government social insurance (table 3.6, line 32) & 1.2 & 5.0 \\
\hline 6 & + & Personal interest income (table 2.1, line 14) & 463.7 & $1,263.9$ \\
\hline 7 & - & Net interest and miscellaneous payments on assets (table 1.7.5, line 20) & 277.5 & 563.1 \\
\hline 8 & + & Government rents and royalties (table 3.2 , line 15 plus table 3.3 , line 15 ) & 8.6 & 18.2 \\
\hline 9 & - & Personal interest payments to business (table 2.1 , line 30 ) & 59.3 & 273.9 \\
\hline 10 & - & Corporate profits tax liability (table 3.2 , line 7 plus table 3.3 , line 10 ) & 63.0 & 246.0 \\
\hline 11 & - & Personal property taxes (table 3.4 , sum of lines 18,19 , and 20 ) & 7.3 & 28.2 \\
\hline 12 & - & Business property taxes (line 4 from this paper's Factor Outlay account in table 1 ) & 103.8 & 511.0 \\
\hline 13 & - & Personal tax and nontax payments (table 2.1 , line 24 ) & 346.9 & $1,116.7$ \\
\hline 14 & - & Federal estate and gift taxes (table 5.11, line 19) & 7.5 & 20.6 \\
\hline 15 & - & State and local estate and gift taxes (table 5.11, line 20) & 2.6 & 4.3 \\
\hline 16 & - & Business transfer payments to foreigners (table 4.1 , line 28 ) & 3.4 & 21.2 \\
\hline 17 & - & Rents and royalties received by the Federal government (table 3.2 , line 15 ) & 5.1 & 7.0 \\
\hline 18 & - & Rents and royalties received by state and local governments (table 3.3 , line 15 ) & 3.5 & 11.2 \\
\hline 19 & - & Dividends received by government (table 3.1 , line 10 ) & 0.2 & 20.9 \\
\hline 20 & $=$ & Gross private national income & $3,036.5$ & $13,416.7$ \\
\hline 21 & + & Nonmarket labor income (sum of lines $18-21$ from this paper's Product account in table 1 ) & $8,513.1$ & $39,658.7$ \\
\hline 22 & $=$ & Full gross private national income & $11,549.6$ & $53,075.4$ \\
\hline 23 & + & Government transfer payments to persons other than benefits from social insurance funds & 97.2 & 757.3 \\
\hline 24 & + & $\begin{array}{l}\text { Government net purchases of nonproduced assets (table } 3.1 \text {, line } 36 \text { ) } \\
\text { Capital transfer payments to persons and financial stablization payments (table } 5.11 \text { sum of lines }\end{array}$ & -1.5 & 3.4 \\
\hline 25 & + & 12-14) & 0.2 & 142.9 \\
\hline 26 & $=$ & Full gross private national consumer receipts & $11,645.5$ & $53,979.0$ \\
\hline \multicolumn{5}{|c|}{ Expenditures } \\
\hline & & & 1982 & 2009 \\
\hline 1 & & Personal consumption expenditures (table 1.1.5, line 2) & $2,073.9$ & $9,842.9$ \\
\hline 2 & - & Personal consumption expenditures, durable goods (table 1.1.5, line 4) & 253.0 & $1,023.3$ \\
\hline 3 & + & Imputation for nonhuman capital services (line 16 of the Product account in table 1 ) & 298.9 & $1,234.6$ \\
\hline 4 & $=$ & Private national consumption expenditure & $2,119.8$ & $\overline{10,054.2}$ \\
\hline 5 & + & Consumption of nonmarket goods and services & $3,944.5$ & $12,311.0$ \\
\hline 6 & $=$ & Full private national consumption expenditure & $6,064.3$ & $22,365.2$ \\
\hline 7 & + & Personal transfer payments to foreigners (table 2.1 , line 33 ) & 6.7 & 66.1 \\
\hline 8 & + & Current Transfer Receipts from persons (table 3.1, line 13) & 7.1 & 83.5 \\
\hline 9 & $=$ & Full private national consumer outlays & $6,078.1$ & $22,514.8$ \\
\hline 10 & + & Full gross private national saving (line 11 of the Saving account in table 8) & $5,567.6$ & $31,464.2$ \\
\hline 11 & $=$ & Full private national consumer expenditures & $11,645.5$ & $53,979.0$ \\
\hline
\end{tabular}

Note: Totals may differ slightly from the sums due to rounding. 
By sub periods, price growth is almost always greater, and usually significantly higher, than quantity growth in the expenditure component and in the consumer outlays and saving subcomponents (see table 7). The only subcomponent and sub period for which quantity growth is greater than price growth is the consumer outlays subcomponent for the 1998-2000 sub period.

The fourth account is the gross private national capital accumulation account (see table 8). This account, as well as demonstrating how full gross private national saving is equal to gross private national capital formation, derives net private national saving and change in private national wealth (see the Saving part of table 8). Depreciation experienced the greatest relative change between 1982 and 2009 in any of the sub components which show the relationship between gross private national saving and change in private national wealth. The 2009 estimates for gross private national saving, human capital saving, and full gross private national saving are all four to six times the corresponding 1982 estimates, however the 2009 estimate for depreciation is well over nine times the corresponding 1982 estimate. As previously noted, human capital depreciation has risen significantly potentially as the result of the aging of the baby-boomer population. Accordingly, the 2009 estimate for net private national saving is only just over two times the corresponding 1982 estimate. As the 2009 estimate for revaluation, which is added to net saving, is just over 1.5 times the 1982 estimate, the 2009 estimate for change in private national wealth is between 1.5 and 2 times the 1982 estimate.

By sub periods, given the relative changes in the magnitudes, it is not surprising that the full net saving quantity growth is negative for all sub periods except for 1949-1984 and 1949-1973 (see table 9). If it were not for the strong growth in the 1949-1973 sub period, the 1949-1984 sub period growth would also be negative. In the 2000-2005 sub period, even the full net saving price growth is negative. With low rates of quantity growth for all components for all sub periods beginning in 1998 or after, quantities per capita growth are all negative as well with one exception: full depreciation in the 2005-2009 sub period.

Figure 10 shows negative contributions for net saving for all periods beginning in 1974 or after as contributions are weighted quantity rates of growth. As full gross private saving is the aggregate, depreciation has a positive contribution. However, this perspective changes when looking at net saving, which is probably the more relevant aggregate. Depreciation contribution is particularly large during the two sub periods when economic growth was lower: 1974-1984 and 2006-2009. During the 2006-2009 sub period, unemployment was high and labor force participation declined, both factors reducing gross and net human saving, the latter due to human depreciation increasing. The human saving quantity reached its maximum for the broader sub period 1999-2005 in 2000, at the end of the “IT Boom" period (see appendix table 16). Accordingly, it is not surprising that the contribution of human saving is a large negative during the 2001-2005 sub period. In this sub period, the contribution of total saving is not appreciably different from zero. 
Table7 Full Private National Expenditures, rates of growth, 1949-1984, 1998-2009

\begin{tabular}{lrrrrrrr}
\hline & $1949-$ & $1949-$ & $1973-$ & $1998-$ & $1998-$ & $2000-$ & $2005-$ \\
& 1984 & 1973 & 1984 & 2009 & 2000 & 2005 & 2009 \\
\hline Full expenditures: & & & & & & & \\
$\quad$ Nominal dollar & 0.0735 & 0.0675 & 0.0865 & 0.0327 & 0.0504 & 0.0212 & 0.0383 \\
Quantity & 0.0224 & 0.0247 & 0.0175 & 0.0105 & 0.0145 & 0.0084 & 0.0111 \\
Quantity per capita & 0.0093 & 0.0101 & 0.0078 & -0.0011 & -0.0071 & -0.0009 & 0.0018 \\
Price & 0.0510 & 0.0427 & 0.0692 & 0.0222 & 0.0357 & 0.0129 & 0.0272 \\
Full consumer outlays: & & & & & & & \\
Nominal dollar & 0.0736 & 0.0653 & 0.0915 & 0.0481 & 0.0524 & 0.0461 & 0.0485 \\
Quantity & 0.0243 & 0.0246 & 0.0235 & 0.0216 & 0.0277 & 0.0221 & 0.0178 \\
Quantity per capita & 0.0112 & 0.0100 & 0.0138 & 0.0100 & 0.0061 & 0.0128 & 0.0085 \\
Price & 0.0493 & 0.0407 & 0.0681 & 0.0265 & 0.0248 & 0.0240 & 0.0305 \\
Full saving: & & & & & & & \\
Nominal dollar & 0.0733 & 0.0697 & 0.0813 & 0.0231 & 0.0493 & 0.0061 & 0.0312 \\
Quantity & 0.0206 & 0.0248 & 0.0114 & 0.0038 & 0.0074 & 0.0001 & 0.0066 \\
Quantity per capita & 0.0075 & 0.0102 & 0.0016 & -0.0077 & -0.0142 & -0.0092 & -0.0027 \\
Price & 0.0527 & 0.0449 & 0.0699 & 0.0193 & 0.0415 & 0.0061 & 0.0247 \\
\hline
\end{tabular}


Table 8 Full Gross Private National Capital Accumulation and Saving, United States, 1982 and 2009 (billions of dollars)

\begin{tabular}{|c|c|c|c|c|}
\hline \multicolumn{5}{|c|}{ Saving } \\
\hline & & & 1982 & 2009 \\
\hline 1 & & Gross private saving NIPA (table 5.1 , line 43 ) & 783.7 & $3,150.7$ \\
\hline 2 & + & $\begin{array}{l}\text { Personal consumption expenditures, durable goods (line } 2 \text { of the Expenditures account in } \\
\text { table 18) }\end{array}$ & 253.0 & $1,023.3$ \\
\hline 3 & + & Surplus, social insurance funds (table 3.14 , line 1 plus line 16 minus lines 10 and 23) & -33.1 & -251.0 \\
\hline 4 & + & Statistical discrepancy (table 5.1, line 42) & 6.8 & 72.2 \\
\hline 5 & - & Taxes on wealth (Estate and gift taxes, table 5.11 line 18) & 10.1 & 24.9 \\
\hline 6 & + & $\begin{array}{l}\text { Government net purchases of nonproduced assets (table } 3.1 \text {, line } 36 \text { ) } \\
\text { Capital transfer payments to persons and financial stablization payments (table 5.11, sum of }\end{array}$ & -1.5 & 3.4 \\
\hline 7 & + & lines $12-14)$ & 0.2 & 142.9 \\
\hline 8 & $=$ & Gross private national saving & 999.0 & $4,116.5$ \\
\hline 9 & + & Human capital saving (sum of lines $19-21$ of the Product account in table 1) & $4,568.6$ & $27,347.7$ \\
\hline 10 & $=$ & Full gross private national saving & $5,567.6$ & $31,464.2$ \\
\hline 11 & - & Depreciation* & $2,624.8$ & $25,060.4$ \\
\hline 12 & $=$ & Net private national saving & $2,942.8$ & $6,403.8$ \\
\hline 13 & + & Revaluation* & $10,643.00$ & $16,509.8$ \\
\hline 14 & $=$ & Change in private national wealth & $13,585.8$ & $22,913.6$ \\
\hline \multicolumn{5}{|c|}{ Capital Formation } \\
\hline \multicolumn{5}{|c|}{ Gross private domestic investment excluding intellectual property products (table 1.1.5, line } \\
\hline 1 & & 7 minus line 12 ) & 508.3 & 1327.2 \\
\hline 2 & + & Intellectual property products (table 1.1 .5 , line 12 ) & 72.7 & 550.9 \\
\hline 3 & + & $\begin{array}{l}\text { Personal consumption expenditures, durable goods (line } 2 \text { of the Expenditures account in } \\
\text { table 18) }\end{array}$ & 253.0 & $1,023.3$ \\
\hline 4 & + & Net lending of federal government (table 3.2, line 45) & 185.4 & $1,476.7$ \\
\hline 5 & + & Net lending of state and local governments (table 3.3, line 38) & 16.1 & 371.4 \\
\hline 6 & - & Deficit, federal social insurance funds (table 3.14 , line 10 minus line 1 ) & 34.3 & 253.1 \\
\hline 7 & - & Deficits, state and local social insurance funds (table 3.14 , line 23 minus line 16) & -1.2 & -2.1 \\
\hline 8 & + & Net foreign investment (Table 4.1, line 29) & -3.4 & -381.7 \\
\hline 9 & $=$ & $\begin{array}{l}\text { Gross private national capital formation } \\
\text { Gross private national human capital formation (sum of lines } 19-21 \text { of the Product account in }\end{array}$ & 999.0 & $4,116.5$ \\
\hline 10 & + & table 1) & $4,568.6$ & $27,347.7$ \\
\hline 11 & $=$ & Full gross private national capital formation & $5,567.6$ & $31,464.2$ \\
\hline
\end{tabular}

Note: Totals may differ slightly from the sums due to rounding.

* For 1982, depreciation and revaluation are taken directly from the original 1989 paper; human and nonhuman depreciation and revaluation are not available separately for that year. 
Table 9 Full Gross Private National Saving, rates of growth, 1949-1984, 1998-2009

\begin{tabular}{lrrrrrrr}
\hline & $1949-$ & $1949-$ & $1973-$ & $1998-$ & $1998-$ & $2000-$ & $2005-$ \\
& 1984 & 1973 & 1984 & 2009 & 2000 & 2005 & 2009 \\
\hline Full gross saving: & & & & & & & \\
$\quad$ Nominal dollar & 0.0733 & 0.0697 & 0.0813 & 0.0231 & 0.0493 & 0.0061 & 0.0312 \\
Quantity & 0.0206 & 0.0248 & 0.0114 & 0.0038 & 0.0074 & 0.0001 & 0.0066 \\
Quantity per capita & 0.0075 & 0.0102 & 0.0016 & -0.0077 & -0.0142 & -0.0092 & -0.0027 \\
Price & 0.0527 & 0.0449 & 0.0699 & 0.0193 & 0.0415 & 0.0061 & 0.0247 \\
Full net saving: & & & & & & & \\
Nominal dollar & 0.0674 & 0.0690 & 0.0639 & 0.0142 & 0.0102 & -0.0248 & 0.0649 \\
Quantity & 0.0157 & 0.0253 & -0.0053 & -0.0234 & -0.0025 & -0.0148 & -0.0446 \\
Quantity per capita & 0.0026 & 0.0107 & -0.0150 & -0.0349 & -0.0240 & -0.0240 & -0.0540 \\
Price & 0.0517 & 0.0437 & 0.0692 & 0.0376 & 0.0127 & -0.0100 & 0.1096 \\
Full depreciation: & & & & & & & \\
Nominal dollar & 0.0816 & 0.0709 & 0.1049 & 0.0255 & 0.0600 & 0.0135 & 0.0233 \\
Quantity & 0.0269 & 0.0237 & 0.0341 & 0.0099 & 0.0107 & 0.0041 & 0.0168 \\
Quantity per capita & 0.0139 & 0.0090 & 0.0244 & -0.0016 & -0.0109 & -0.0052 & 0.0075 \\
Price & 0.0546 & 0.0471 & 0.0709 & 0.0156 & 0.0497 & 0.0092 & 0.0066 \\
\hline
\end{tabular}


Figure 10 Contributions to Full Gross Private National Saving

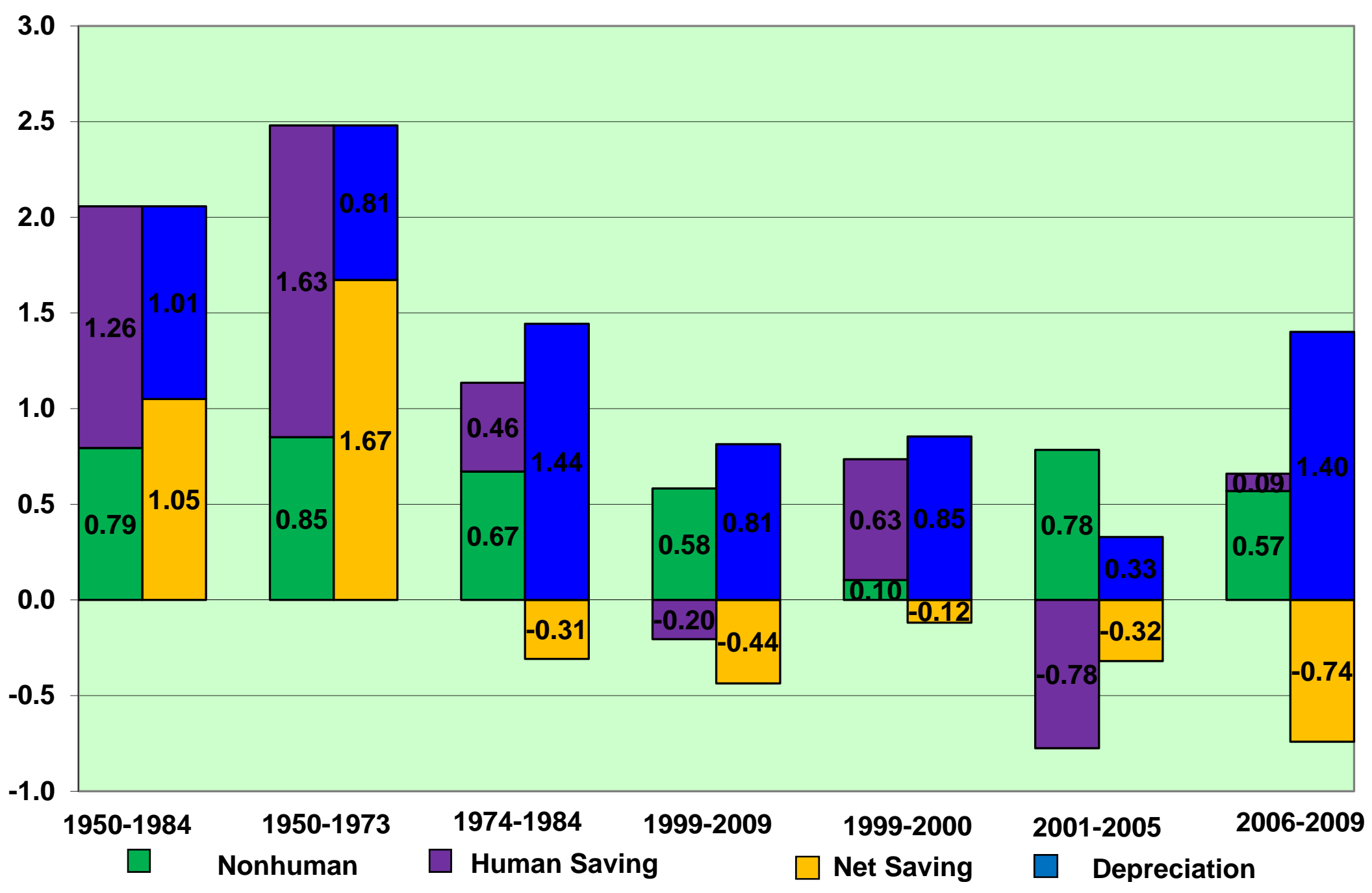


Figure 11 combines information from the income account of table 4, the full private consumer outlays component of table 6 , and the net private national saving component of table 8 . In this figure, growth in the level of living is the difference between growth rates of expenditures and incomes. Total growth is the highest in the 1950-1973 sub period. Half of the subcomponents experience a maximum contribution in this sub period: labor income, level of living, and net saving. In all sub periods starting in 1973 or after, as just described, the contribution of net saving is negative. The contribution of market consumption is the highest over all sub periods in1999-2000 at the end of the "IT Boom" period, and continues to be an important contributor in 1999-2000 at the end of the "IT Boom" period, and continues to be an important contributor in the 2001-2005 sub period before reaching its minimum during the 2006-2009 Great Recession and slow recovery sub period. The level of living contribution is even negative during this last sub period. The contribution of market consumption, which is the contribution of time in household production and leisure, is lower in all sub periods beginning in 1999 than in all previous sub periods.

The fifth, and last account, is for full private national wealth (see table 10). Using either nominal shares or contributions to examine subcomponents of wealth, the magnitudes for human wealth clearly dominate (see figures 8 and 12 and appendix table 22). The magnitudes of private domestic tangible assets, which are clearly larger than the magnitudes of net claims on governments and the rest-of-the world, are small compared to the magnitude for human wealth. Tangible assets represent clearly less than 10 percent of full private national wealth.

By sub periods (see table 11), price growth is almost always greater than quantity growth. Both exceptions are for nonhuman wealth. In the sub period 1949-1973, nonhuman wealth price and quantity grow at a relatively strong rate (approximately between three and four percent), with quantity growth being greater. In the sub period 2005-2009, the nonhuman wealth price decreased at a very large rate. For human wealth, in the earlier period, 1949-1984, the difference between the price rate of growth and the quantity rate of growth is over three and one-half percentage points; in the later period, 1998-2009, this difference fell by over one percentage points.

The final figure (see figure 12) shows the contribution of nonhuman versus human wealth to growth in full private national wealth. The significant variation in growth in sub period 19501973 compared to 1974-1984 can be attributed to the contribution of human wealth, which is well over one percent in each of these sub periods. The contribution of human wealth to growth in total wealth continued to be strong in all later sub periods, but it is always less than one percent. As figure 1 illustrates, average educational attainment for those aged 15 through 74 increased at a rapid rate from 1950 to 1980, with the rate of increase substantially slowing from 1980 to 2010. In the earlier three sub periods and again in 2001-2005, nonhuman wealth contributes .25 percentage points to growth in total wealth. Its contribution is less in 1999-2009, 1999-2000 and 2006-2009. The decrease in both the contribution of human and nonhuman 
Figure 11 Contributions to Full Private National Expenditure and Income

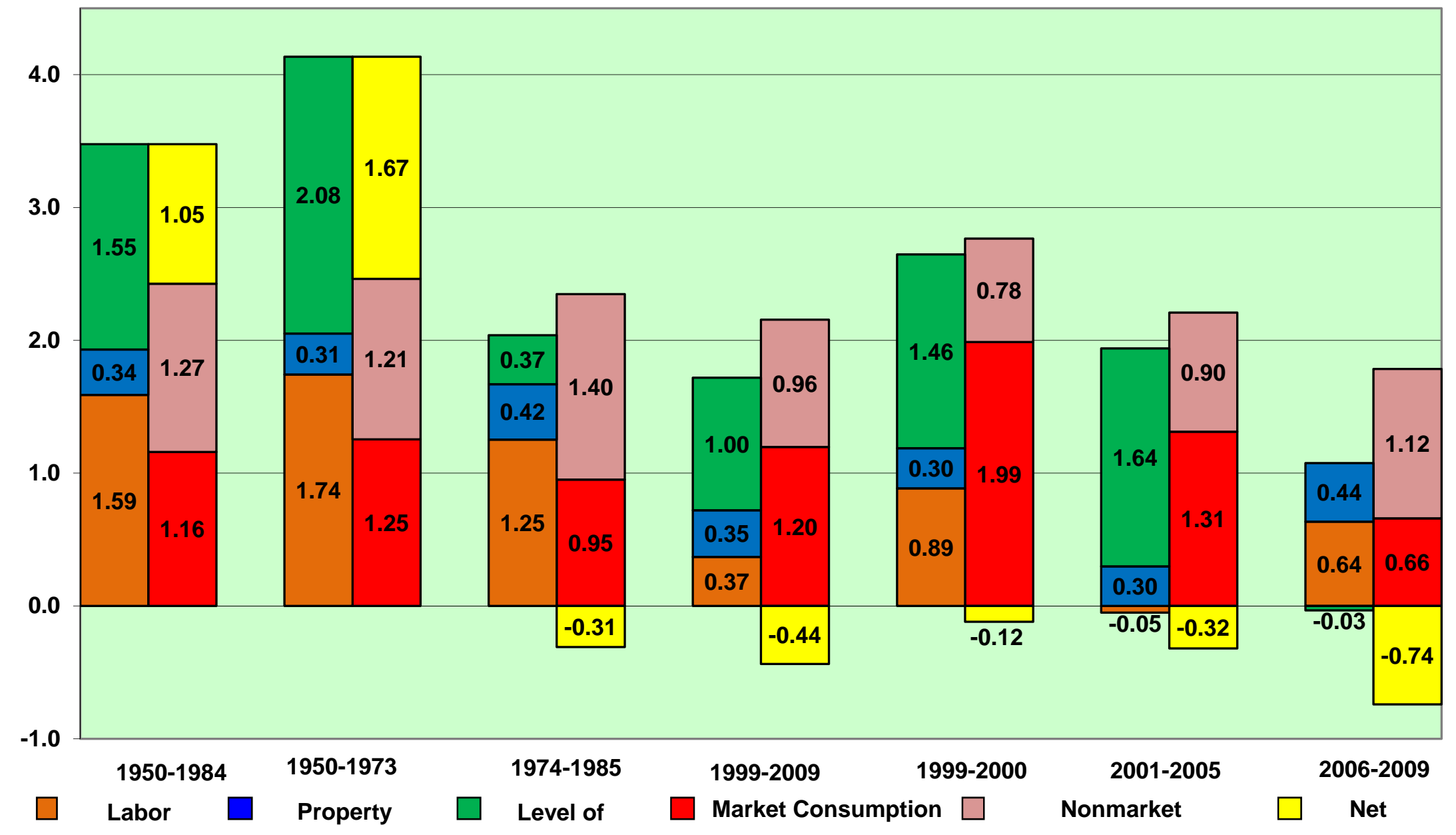


Table 10 Full Private National Wealth, United States, 1982 and 2009 (billions of current dollars)

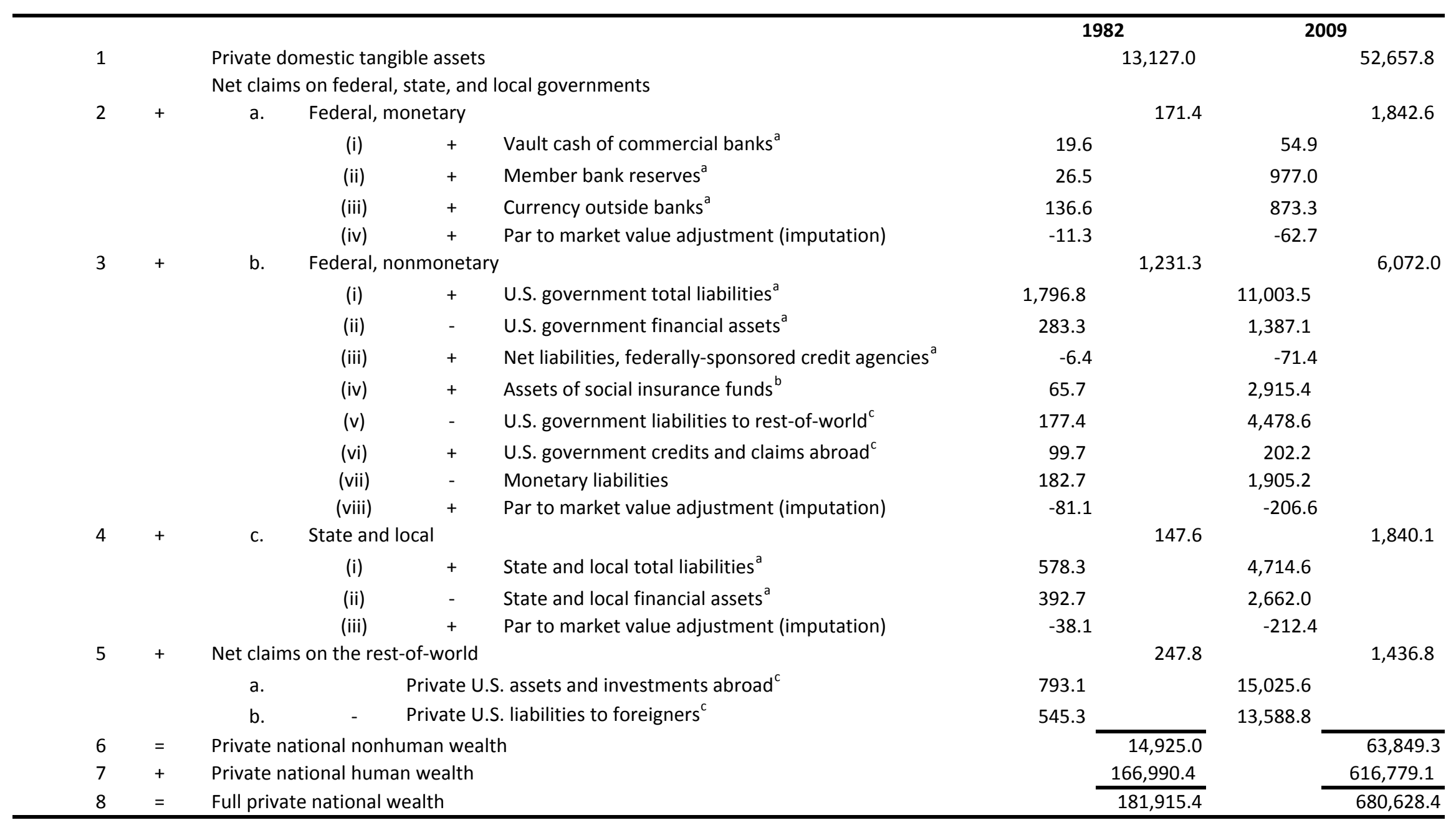

Note: Totals may differ slightly from the sums due to rounding.

${ }^{a}$ Board of Governors of the Federal Reserve System, Flow of Funds Accounts, various issues.

${ }^{b}$ U. S. Department of Treasury, Treasury Bulletin , February issues.

c "The International Investment Position of the United States," Survey of Current Business, various issues. 
Table 11 Full Private National Wealth, rates of growth, 1949-1984, 1998-2009

\begin{tabular}{lrrrrrrr}
\hline & $1949-$ & $1949-$ & $1973-$ & $1998-$ & $1998-$ & $2000-$ & $2005-$ \\
& 1984 & 1973 & 1984 & 2009 & 2000 & 2005 & 2009 \\
\hline Full wealth: & & & & & & & \\
$\quad$ Nominal dollar & 0.0725 & 0.0684 & 0.0815 & 0.0418 & 0.0492 & 0.0464 & 0.0323 \\
Quantity & 0.0191 & 0.0206 & 0.0158 & 0.0097 & 0.0111 & 0.0102 & 0.0084 \\
Quantity per capita & 0.0060 & 0.0059 & 0.0061 & -0.0018 & -0.0105 & 0.0009 & -0.0009 \\
Price & 0.0536 & 0.0480 & 0.0658 & 0.0320 & 0.0377 & 0.0363 & 0.0239 \\
Human wealth: & & & & & & & \\
Nominal dollar & 0.0721 & 0.0686 & 0.0797 & 0.0411 & 0.0461 & 0.0403 & 0.0398 \\
Quantity & 0.0178 & 0.0194 & 0.0144 & 0.0083 & 0.0104 & 0.0085 & 0.0070 \\
Quantity per capita & 0.0047 & 0.0048 & 0.0046 & -0.0032 & -0.0112 & -0.0007 & -0.0024 \\
Price & 0.0543 & 0.0492 & 0.0653 & 0.0328 & 0.0357 & 0.0318 & 0.0328 \\
Nonhuman wealth: & & & & & & & -0.0299 \\
Nominal dollar & 0.0776 & 0.0655 & 0.1041 & 0.0484 & 0.0808 & 0.0980 & -0.028 \\
Quantity & 0.0354 & 0.0362 & 0.0337 & 0.0219 & 0.0179 & 0.0246 & 0.0205 \\
Quantity per capita & 0.0223 & 0.0216 & 0.0239 & 0.0104 & -0.0037 & 0.0154 & 0.0112 \\
Price & 0.0421 & 0.0292 & 0.0701 & 0.0264 & 0.0627 & 0.0734 & -0.0505 \\
\hline
\end{tabular}


Figure 12 Contributions to Full Private National Wealth

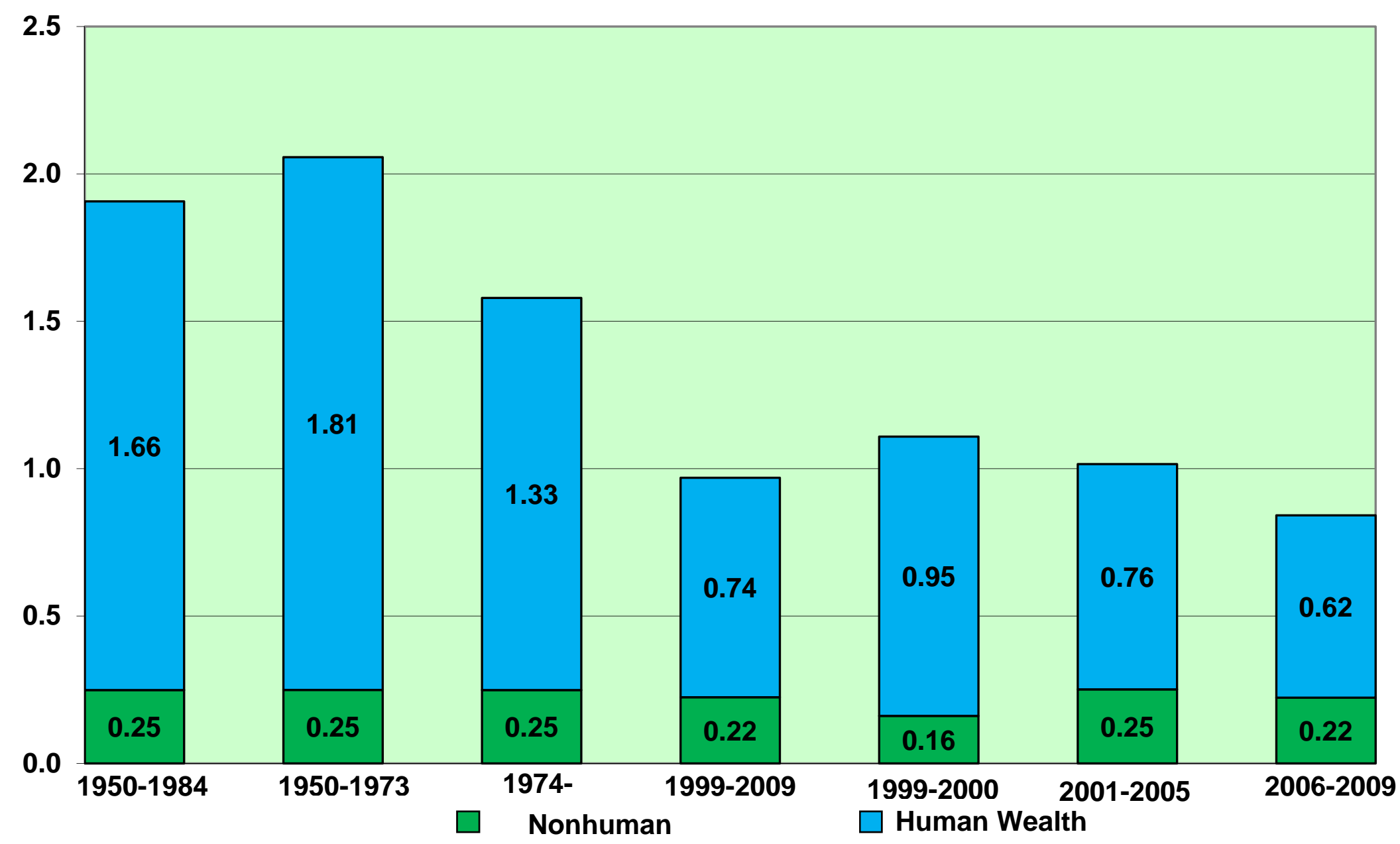


wealth results in total growth in the later period being almost always at least one percentage point lower than in the earlier period.

\section{Conclusion}

Without looking at a set of national accounts with integrated human capital components, researchers, analysts, and policy-makers will have an incomplete picture of economic growth. Major economic trends are very much evident in the results: the slowdown in the sub period 1974- 1984 relative to the sub period 1950-1984, the rebound in the sub period 1999-2000 at the end of the "IT Boom" period, another slowdown in the sub period 2001-2005, followed by a weak economy in the sub period 2006-2009. The benefit from integrating human capital components most clearly comes from quantification of the impact of an end to the gains in average educational attainment and female labor force participation and the greying of America. Recently, in a number of countries including China and India, the average educational attainment of the young aged 25 through 34 have substantially surpassed the average educational attainment of the older aged 55 through $64 .^{23}$ By contrast, in 2010 the average educational attainment of the young in the United States is barely above the average educational attainment of older individuals. ${ }^{24}$ A typical situation is for sub period price growth to be larger than quantity growth. The contribution of net saving is negative in all sub periods beginning on or after 1974 and depreciation more than doubled as a share of gross saving between 1949 and 2009 (see appendix table 19). ${ }^{25}$ What does it mean in a world economy to have price growth to be larger than quantity growth? How will the decrease in the contribution of human capital play out in the future? Will the economies of many other countries, particularly emerging countries, continue to catch up, and if so, at what pace? Does this mean that the United States government should be encouraging policies to increase investment in human capital? The answers to these questions are unknown, but they can best be explored using accounts which include human capital components.

\footnotetext{
${ }^{23}$ See Fraumeni and Liu (2014).

${ }^{24}$ See the Barro-Lee data set (Barro and Lee, 2013b).

${ }^{25}$ For all years, 1998 through 2009, human depreciation is approximately 90 percent of total depreciation.
} 


\section{Bibliography}

Ahlroth, S. A. and A. F. Bjorklund, "The Output of the Swedish Education Sector," Review of Income and Wealth Volume 43, Number 1, pp.89-104, 1997.

Barro, R. \& J. Lee, "A New Data Set of Educational Attainment in the World, 19502010,” Journal of Development Economics. 104(C). p. 184-198, 2013 a.

Barro, R. \& J. Lee, Barro-Lee Educational Attainment Data Set. Last updated April 9, 2013. Retrieved October 2013 from http://www.barrolee.com/, 2013b.

Boskin, M. J., "Getting the 21st-Century GDP Right, Economic Measurement: Progress and Challenges,” American Economic Review, Papers and Proceedings, volume 90, no. 2, May, pp. $247-252,2000$.

Christensen, L. R. and D. W. Jorgenson, "Measuring Economic Performance in the Private Sector," 1973, in D.W. Jorgenson, ed., (1995) Postwar U.S. Economic Growth, Cambridge, The MIT Press, pp. 175-272, 1995.

Christian, M. S., "Human Capital Accounting in the United States: 1994 to 2006," paper presented at the Bureau of Economic Analysis, December 14, 2009.

—_, "Human Capital Accounting in the United States: 1994 to 2006," Survey of Current Business, 87(6), pp. 78-83, 2010.

— - "Human Capital Accounting in the United States: Context, Measurement, and Application,” in D. W. Jorgenson, J. S. Landefeld, and P. Schreyer, eds. Measuring Economic Sustainability and Progress, Studies in Income and Wealth, volume 72, Chicago, University of Chicago Press, NBER, pp. 461-491, 2014.

Colby, S. L. and J. M. Ortman,“The Baby Boom Cohort in the United States: 2012 to 2060,” Current Population Reports, Population Estimates and Projections, P25-1141, May 2014.

Coremberg, A., "The Economic Value of Human Capital and Education in an Unstable Economy: the Case of Argentina,” paper prepared for the 31st General Conference of the International Association for Research in Income and Wealth, St. Gallen, Switzerland, August 22-28, 2010. 
Fraumeni, B.,"Human Capital and Investment in Education: A Streamlined Approach” presentation at a Fondazione Giovanni Agnelli/OE CD workshop on human capital accounts, Turin, Italy, November 3, available at http://www.

powershow.com/view/132efc-OTZlY / Barbara_M_Fraumeni_flash_ppt_presentation, 2008a.

Fraumeni, B. M., "Human Capital: From Indicators to Accounts,” paper presented at a Fondazione Giovanni Agnelli/OECD workshop on human capital accounts, Turin, Italy, November 4, 2008b.

Fraumeni, B.M. and G. Liu, "Human Capital: Country Estimates Using Alternative Approaches," chapter 4 in UNU-IHDP and UNEP (2014). Inclusive Wealth Report 2014, Measuring Progress Toward Sustainability, Cambridge: Cambridge University Press, pp. 109122, 2014.

Gundimeda, H., S. Sanyal, R. Sinha, and P. Sukhdev, "Estimating the Value of Educational Capital Formation in India,” Monograph 5, GAISP (Green Accounting for Indian States Project), TERI Press, New Delhi, India, March, 2007.

Gu, W. and A. Wong, "Human Development and its Contribution to the Wealth Accounts in Canada," paper presented at the Canadian Economic Association Annual Conference, May 29, 2009.

Hotchkiss, J. and M. Shiferaw "Decomposing the Education Wage Gap: Everything but the Kitchen Sink,” Federal Reserve Bank of St. Louis Review, 93(4), pp. 243-71, July/August 2011.

Jorgenson, D. W., “Accounting for Capital,” in G. von Furstenberg, (ed.), Capital, Efficiency, and Growth, Cambridge, Ballinger, 1980, pp. 251-319, 1980.

Jorgenson, D. W., "Designing a New Architecture for the U.S. National Accounts." The Annals of the American Academy of Political and Social Science 631, no. 1, pp. 63-74, 2010.

Jorgenson, D. W. and B. M. Fraumeni, "The Accumulation of Human and Non-Human Capital, 1948-1984," in R. Lipsey and H. Tice eds., The Measurement of Saving, Investment and Wealth, Chicago, University of Chicago Press, NBER, pp. 227-282, 1989.

_- "Investment in Education and U.S. Economic Growth," Scandinavian Journal of Economics, Vol. 94, supplement, pp. S51-70, 1992a.

—_ "The Output of the Education Sector," in Z. Griliches, T. Breshnahan, M. Manser, and E. Berndt eds., The Output of the Service Sector, Chicago, NBER, pp. 303-341, 1992b.

Jorgenson, D.W., M. S. Ho, and J.D. Samuels, J.D., "What will revive U.S. Economic Growth? Lessons from a Prototype Industry-Level Production Account for the United States," Journal of Policy Modeling, Volume 34, No 4, July-August, pp. 674-691, 2014. 
Jorgenson, D. W. and J. S. Landefeld, "Blueprint for Expanded and Integrated U.S. Accounts: Review, Assessment, and Next Steps," in D. W. Jorgenson, J. S. Landefeld, and W. D. Nordhaus, eds. A New Architecture for the U.S. National Accounts, Chicago, University of Chicago Press, NBER, pp. 13-112, 2006.

Jorgenson, D. W., and J. S. Landefeld, "Implementation of a New Architecture for the U.S. National Accounts," American Economic Review, Papers and Proceedings, volume 99, number 2, May, pp. 64-68, 2009.

Le, T. V. T., J. Gibson, and L. Oxley, "Measuring the Stock of Human Capital in New Zealand," Mathematics and Computers in Simulation, Volume 68, Issue 5-6, May, pp. 485-98, 2005.

Li, H., B. Fraumeni, Z. Liu, and X. Wang, "Human Capital in China," China Center for Human Capital and Labor Market Research, Central University of Finance and Economics, Beijing, China, October 6, 2009, Prepared for the International Symposium on Measuring Human Capital and Its Impact on Welfare and Growth: Inaugurating the China Human Capital Index, in English and Chinese, Beijing, China, October 9-10, 2009a.

_ _ "Human Capital in China," National Bureau of Economic Research Working Paper \#1500, November, 2009b.

Li, H., Y. Liang, B. Fraumeni, Z. Liu, and X.Wang, “China’s Human Capital Measurement and Index Construction,” Economic Research Journal, in Chinese, August, pp. 42-54, 2010 a.

Li, H., Principal Investigator, "Human Capital in China," China Center for Human Capital and Labor Market Research, Central University of Finance and Economics, Beijing, China, October, 2010b.

_- "Human Capital in China," China Center for Human Capital and Labor Market Research, Central University of Finance and Economics, Beijing, China, October, 2011.

_ - "Human Capital in China," China Center for Human Capital and Labor Market Research, Central University of Finance and Economics, Beijing, China, December, 2012.

_- "Human Capital in China," China Center for Human Capital and Labor Market Research, Central University of Finance and Economics, Beijing, China, December, 2013.

__ , "Human Capital in China," China Center for Human Capital and Labor Market Research, Central University of Finance and Economics, Beijing, China, October, 2014. 
Li, H., Y. Liang, B. Fraumeni, Z. Liu, and X.Wang, "Human Capital in China,1985-2008," Review of Income and Wealth, series 59, number 2, June, pp. 212-234, 2013.

Li, H. Q. Liu, B. Li, B. Fraumeni and X. Zhang, "Human Capital Estimates in China: New Panel Data 1985-2010," in China Economic Review, with Haizheng Li, Qinyi Liu, Bo Li, and Xiaobei Zhang, volume 30, issue C, 2014, pp. 397-418, 2014.

Liu, G. and M. Greaker, "Measuring the Stock of Human Capital for Norway - A Lifetime Labour Income Approach,” Documents, 2009/12, Statistics Norway, 2009.

Liu, G., "Measuring the Stock of Human Capital for International and Intertemporal Comparisons," in D. W. Jorgenson, J. S. Landefeld, and P. Schreyer, eds. Measuring Economic Sustainability and Progress, Studies in Income and Wealth, volume 72, Chicago, University of Chicago Press, NBER, pp. 493-544, 2014.

—_ "Measuring the Stock of Human Capital for Comparative Analysis: An Application of the Lifetime Income Approach to Selected Countries," OECD Statistics Directorate, Working Paper \#41, STD/DOC(2011)6, October 10, 2011.

OECD, Statistics Directorate, Committee on Statistics, Approaches to Measuring the Stock of Human Capital: A Review of Country Practices, prepared by R. Boarini and M. Mira d'Ercole with contributions by G. Liu, OECD Working Paper \#48, STD/DOC(2012)4, November 23 ${ }^{\text {rd }}$, 2012.

OECD, Statistics Directorate, Committee on Statistics, The OECD Human Capital Project: Progress Report, STD/CSTST/RD(2010)3, Meeting of the Committee on Statistics, June 7-8, OECD Conference Centre, OECD Headquarters, Paris, May, 2010.

O'Mahony, M. and P.A. Stevens, "International Comparisons of Performance in the Provision of Public Services: Outcome Based Measures for Education,” National Institute of Economic and Social Research, London, U.K., 2004.

Statistics Norway, "How to Take the UNECE Task Force on Measuring Human Capital Forward? A Note for Discussion,” January, 2014.

Stiglitz J.E., A. Sen and J.-P. Fitoussi, Report by the Commission on the Measurement of Economic Performance and Social Progress, http://www.stiglitz-sen-fitoussi.fr/documents/rapport_anglais.pdf, 2009.

U.S. Census Bureau, "Historical National Population Estimates: July 1, 1948 to July 1, 1999,” Population Estimates Program, Population Division, Internet Release Date: April 11, 2000, Revised date: June 28, 2000, https://www.census.gov/population/estimates/nation/popclockest.txt . 
U.S. Census Bureau, "Table 1. Intercensal Estimates of the Resident Population by Sex and Age for the United States: April 1, 2000 to July 1, 2010,” tables by sex and age, file US-ENT00INT01, http://www.census.gov/popest/data/intercensal/national/nat2010.html .

U.S. Census Bureau, Statistical Abstract of the United States: 2012 (131st Edition) Washington, DC, 2011; http://www.census.gov/compendia/statab/

U.S. Census Bureau (2000) "Historical National Population Estimates: July 1, 1948 to July 1, 1999," Population Estimates Program, Population Division, Internet Release Date: April 11, 2000, Revised date: June 28, data collected from website on January 11, 2015 from https://www.census.gov/population/estimates/nation/popclockest.txt .

U.S. Census Bureau (undated) "Table 1. Intercensal Estimates of the Resident Population by Sex and Age for the United States: April 1, 2000 to July 1, 2010," tables by sex and age, file USENT00INT-01, data collected from website on January 11, 2015 from http://www.census.gov/popest/data/intercensal/national/nat2010.html .

U.S. Census Bureau, Statistical Abstract of the United States: 1951, Washington, DC, 2011.

U.S. Department of Commerce, Bureau of Economic Analysis, Survey of Current Business, various issues.

UNU-IHDP and UNEP. Inclusive Wealth Report 2014. Measuring Progress Toward Sustainability. Cambridge: Cambridge University Press, 2014.

Wei, H., "Developments in the Estimation of the Value of Human Capital in Australia," paper presented at the Fondazione Giovanni Agnelli/OECD Workshop on the Measurement of Human Capital, Turin, Italy, November 3, 2008.

—_ "Measuring Australia's Human Capital Development: The Role of Post-School Education and the Impact of Population Ageing," Statistical Journal of the IAO, S 24, pp. 183-191, 2007.

World Bank, The Changing Wealth of Nations-- Measuring Sustainable Development in the New Millennium, The World Bank, Washington, D.C, 2010. 


\section{Appendix}

The appendix to this paper is posted at http://iariw.org/c2015oecd.php at the end of the session 7 version of the Fraumeni, Christian, and Samuels paper. All of the time series tables in the original Jorgenson and Fraumeni 1989 accumulation paper are reproduced in that appendix. These tables are revised and updated, and include the new data for the 1998-2009 period. 